\title{
Literature Review: Analisis Senyawa Aktif Ekstrak Dan Fraksi Tanaman Berpotensi Sebagai Antiplatelet
}

\author{
Virena Audelia Rambang ${ }^{1 *}$, Fatmaria $^{2}$, Natalia Sri Martani ${ }^{3}$ \\ ${ }^{1}$ Graduated student Program Studi Pendidikan Dokter Fakultas Kedokteran Universitas Palangka Raya, Indonesia \\ ${ }^{2}$ Departemen Farmakoterapi, ${ }^{3}$ Departemen Mikrobiologi Fakultas Kedokteran Universitas Palangka Raya, Indonesia \\ *e-mail: virenaaudeliarambang@gmail.com
}

\begin{abstract}
Stroke is still the main cause of morbidity and mortality in the world. Research found "aspirin resistant" in 5-60\% of cases, it's necessary to develop researches related to antiplatelet therapy. In the antiplatelet research on plant extracts, some were significant and some weren't. To determine active compound of plant extracts, fractions, mechanism of action, extraction method, isolation methods of active compounds with antiplatelet activity. Literature studies with a systematic approach, data from original articles in GoogleScholar, PubMed. Obtained 32 literatures through data quality analysis and topic suitability. Data synthesis using PICO method. 30 journals significantly have antiplatelet activity, 2 weren't, the most found compounds were flavonoids, quercetin. Mechanism of action as an antiplatelet, antithrombotic. Extraction methods maceration, reflux, juice, sonication, soxhlet, distillation. The isolation methods using CC, HPLC, TLC, NMR. Conclusion: Insignificant results are from AGE and raw, boiled, fried garlic, both tested in vivo. Journals that significantly have antiplatelet results are from extracts of strawberries, grape seeds, Allium sp., Bay leaves, mango peel, tomatoes, Hawthorn, C.aromatica Salisb., Red ginger, G.verrucosa, S.polycystum, olive leaves, M.alba, P.baumii, R.vernicflua, A.shikokiana, katuk leaves, tempuyung leaves, red cabbage, M.obovata, lempeni leaves, kajajahi leaves, starfruit leaves, U.macrocarpa, M.citrifolia, C.limon, L.japonica, E.bicyclis, S.deserta, V.labrusca. Most found active compound with antiplatelet activity are flavonoids, fraction quercetin. Mechanism of action on COX-1, AA, TXA2, P13K pathways, increased cAMP, VASP stimulation. Extraction methods by maceration, reflux, soxhlet, sonication, juice, distillation. Isolation methods using CC, HPLC, TLC, NMR
\end{abstract}

Key words: antiplatelet, active compound, extract, fraction

\begin{abstract}
Abstrak
Stroke masih menjadi penyebab utama kesakitan dan kematian di dunia. Penelitian menemukan "aspirin resisten" dalam 5-60\% kasus, perlu lebih dikembangkannya penelitian terkait terapi antiplatelet. Pada penelitian antiplatelet terhadap ekstrak tanaman, ada yang signifikan dan yang tidak. Mengetahui senyawa aktif ekstrak, fraksi tanaman, mekanisme kerja, metode ekstraksi, dan cara isolasi senyawa aktif dengan aktivitas antiplatelet. Studi/kajian literatur dengan pendekatan systematic review, sumber data dari original article pada database GoogleScholar, PubMed. Didapatkan 32 literatur melalui analisis kualitas data dan kesesuaian topik. Sintesis data menggunakan metode PICO. 30 jurnal secara signifikan memiliki aktivitas, 2 tidak, senyawa paling banyak ditemukan flavonoid, fraksinya kuersetin. Mekanisme kerja senyawa sebagai antiplatelet, antitrombotik. Metode ekstraksi maserasi, refluks, jus, sonikasi, soxhlet, destilasi. Metode isolasi dengan KK, HPLC, KLT, NMR. Hasil menyatakan tidak memiliki aktivitas antiplatelet dari AGE dan bawang putih yang diolah mentah, rebus, goreng, keduanya diuji in vivo. Hasil menyatakan memiliki aktivitas antiplatelet dari ekstrak stroberi, biji anggur, Allium sp., daun salam, kulit mangga, tomat, daun Hawthorn, C.aromatica Salisb., rimpang jahe merah, G.verrucosa, S.polycystum, daun zaitun, M.alba, P.baumii, R.vernicflua, A.shikokiana, daun katuk, daun tempuyung, kubis merah, M.obovata, daun lempeni, daun kajajahi, daun belimbing wuluh, U.macrocarpa, M.citrifolia, C.limon, L.japonica, E.bicyclis, S.deserta, V.labrusca. Senyawa aktif paling banyak ditemukan memiliki aktivitas antiplatelet flavonoid, fraksinya kuersetin. Mekanisme kerja pada jalur COX-1, AA, TXA2, P13K, peningkatan cAMP, stimulasi VASP. Metode ekstraksi senyawa aktif dengan maserasi, refluks, soxhlet, sonikasi, jus, destilasi. Metode isolasi senyawa aktif dengan KK, HPLC, KLT, NMR.
\end{abstract}

Kata kunci: antiplatelet, senyawa aktif, ekstrak, fraksi 


\section{PENDAHULUAN}

Penyakit kardiovaskular seperti stroke, masih menjadi salah satu penyebab utama kesakitan dan kematian di dunia. Menurut World Health Organization (WHO), pada 2016 stroke sebagai penyakit tidak menular menempati urutan kedua sebagai penyebab kematian, dan urutan ketiga dalam penyebab disabilitas di seluruh dunia. ${ }^{1}$ Stroke, sindrom klinis yang ditandai dengan terjadinya defisit neurologis di otak baik fokal maupun global, dapat berlangsung lebih dari 24 jam dan dapat menyebabkan kematian. ${ }^{2,3}$ Di negara maju, stroke menjadi penyebab nomor satu admisi pasien ke rumah sakit, data American Heart Association (AHA) menyebutkan bahwa setiap 40 detik terdapat 1 kasus baru stroke dengan prevalensi 795.000 pasien stroke baru atau berulang terjadi setiap tahunnya dan setiap 4 menit terdapat 1 pasien stroke yang meninggal. ${ }^{4}$ Di Indonesia, stroke menjadi penyakit nomor satu yang mematikan. Menurut data Kementerian Kesehatan Republik Indonesia tahun 2014, penyebab kematian tertinggi di Indonesia disebabkan oleh stroke dengan persentase $21,1 \%{ }^{5}$

Di Kalimantan Tengah, prevalensi penyakit stroke berdasarkan diagnosis dokter pada penduduk berusia lebih dari sama dengan 15 tahun menurut Riset Kesehatan Dasar tahun 2018 adalah sebesar 12,1\%. ${ }^{6}$
Stroke yang lebih sering ditemukan adalah stroke iskemik yang disebabkan oleh adanya trombosis $(87 \%)$ daripada stroke hemoragik $(13 \%)^{7}$

Pengobatan untuk trombosis adalah antiplatelet, antikoagulan, dan trombolisis. Salah satu obat yang digunakan sebagai terapi antiplatelet adalah asetosal atau aspirin. Aspirin dapat menghambat agregasi platelet pada jalur tromboksan $\mathrm{A}_{2}$ dan enzim Cyclooxygenase-1 (COX-1). Namun, beberapa penelitian mendapatkan adanya "aspirin resisten", efek yang inadekuat dari aspirin, dalam 5-60\% kasus, dengan variasi kondisi yang sangat beragam. Resisten dapat dibedakan menjadi secara klinis maupun laboratorium. Dalam hal ini, "resistensi" tersebut disebabkan oleh banyak sekali faktor, seperti respon individual tubuh masing-masing pasien dalam menerima terapi aspirin, kepatuhan pasien minum obat, absorbansi, bioavabilitas, variasi genetik, dan aktivasi platelet dari jalur-jalur lain., ${ }^{8,9}$

Variasi yang sangat beragam ini mengakibatkan perlu lebih gencar dikembangkannya penelitian terkait terapi antiplatelet. Penting untuk diteliti lebih lanjut mengenai terapi dengan produk alamiah untuk menemukan senyawa-senyawa baru dan mengembangkan obat-obatan baru. Tanaman herbal, dengan segala variasi senyawa aktif yang dikandungnya memiliki peranan penting dalam mempertahankan kesehatan di seluruh dunia, 
berdasarkan data oleh WHO, diperkirakan sekitar $80 \%$ dari populasi menggunakan ekstrak tanaman dan/atau senyawa aktifnya dalam dunia kesehatan. Dikatakan pula bahwa 30\% dari obat-obatan sintetik merupakan derivat dari tanaman dan mikroorganisme. Namun, tentunya harus dilakukan kembali penelitian lebih mendalam untuk mengetahui efek samping dan dosis yang tepat. ${ }^{8,10,11}$

Pada penelitian-penelitian terdahulu, telah ditemukan beberapa senyawa aktif yang terdapat dalam tanaman yang terbukti dapat menghambat agregasi platelet. Pada penelitian uji aktivitas antiplatelet yang dilakukan terhadap senyawa aktif fraksi isolasi dari beberapa ekstrak tanaman Zingiberaceae sp., menunjukkan bahwa dari 12 senyawa aktif fraksi isolasi tersebut, terdapat 4 senyawa aktif yang memiliki aktivitas antiplatelet paling kuat dalam menghambat agregasi platelet yang terinduksi Asam Arakidonat (AA), kolagen, dan Adenosine-6-diphosphate (ADP), yaitu senyawa aktif zerumbone, xanthorrhizol, kurkumin, dan xanthorrhizol epoxide. Beberapa senyawa lainnya juga menunjukkan adanya hasil yang signifikan dalam menghambat agregasi platelet. Namun, didapatkan satu senyawa yang tidak menunjukkan hasil signifikan dalam menghambat agregasi platelet, yaitu senyawa aktif derivat 5methoxyflavanon. ${ }^{12}$ Selain itu, ada pula hasil penelitian lain yang mendapatkan hasil tidak signifikan. Penelitian tersebut menunjukkan bahwa bawang putih (Allium sativum L.) yang diekstraksi dan didiamkan selama 10 bulan (Aged Garlic Extract) tidak efektif dalam memperpanjang waktu perdarahan mencit,. Hal ini menunjukkan bahwa ada faktor-faktor yang dapat menyebabkan ditemukannya perbedaan hasil antara satu penelitian dengan penelitian yang lainnya. Faktor tersebut dapat berupa tidak ada atau hilangnya mekanisme aksi dari beberapa senyawa aktif yang tidak signifikan tersebut dalam menghambat salah satu maupun semua jalur induksi agregasi platelet (baik AA, ADP, maupun kolagen). Faktor lainnya dapat pula dikarenakan senyawa aktif yang di uji tersebut bersifat dan berespon secara non-dose dependent..$^{12,13}$

Hal ini menjadi topik yang menarik bagi peneliti untuk dilakukan sebuah telaah literatur untuk disusun menjadi sebuah karya ilmiah baru. Senyawa-senyawa aktif apa saja yang memiliki potensi memiliki aktivitas antiplatelet, bagaimana mekanisme aksinya dalam menghambat agregasi platelet, dan bagaimana metode ekstraksi serta metode isolasi fraksi senyawa aktif yang memiliki aktivitas antiplatelet menjadi topik yang menarik bagi peneliti. Berdasarkan latar belakang tersebut, peneliti ingin menelaah, mengkaji secara kritis, 
menganalisis, dan menyintesis data dari sisi senyawa-senyawa aktif dalam tanaman yang memiliki potensi sebagai antiplatelet, dengan harapan dapat berguna bila dilakukan lagi penelitian baru dan pengembangan terapi alternatif baru untuk mengatasi permasalahan yang ada.

\section{BAHAN DAN METODE}

Jenis penelitian ini adalah penelitian kepustakaan atau kajian literature (literature research, literature review) dengan pendekatan systemic review. Sumber data diperoleh dari data sekunder dari original article pada website seperti PubMed dan Google Scholar. Sampel ditemukan sebanyak 32 jurnal yang terdiri dari 14 jurnal nasional dan 18 jurnal internasional. Sintesis data menggunakan metode PICO.

\section{HASIL PENELITIAN}

Tabel 3.1 Hasil Sintesis Data

Original Article 1

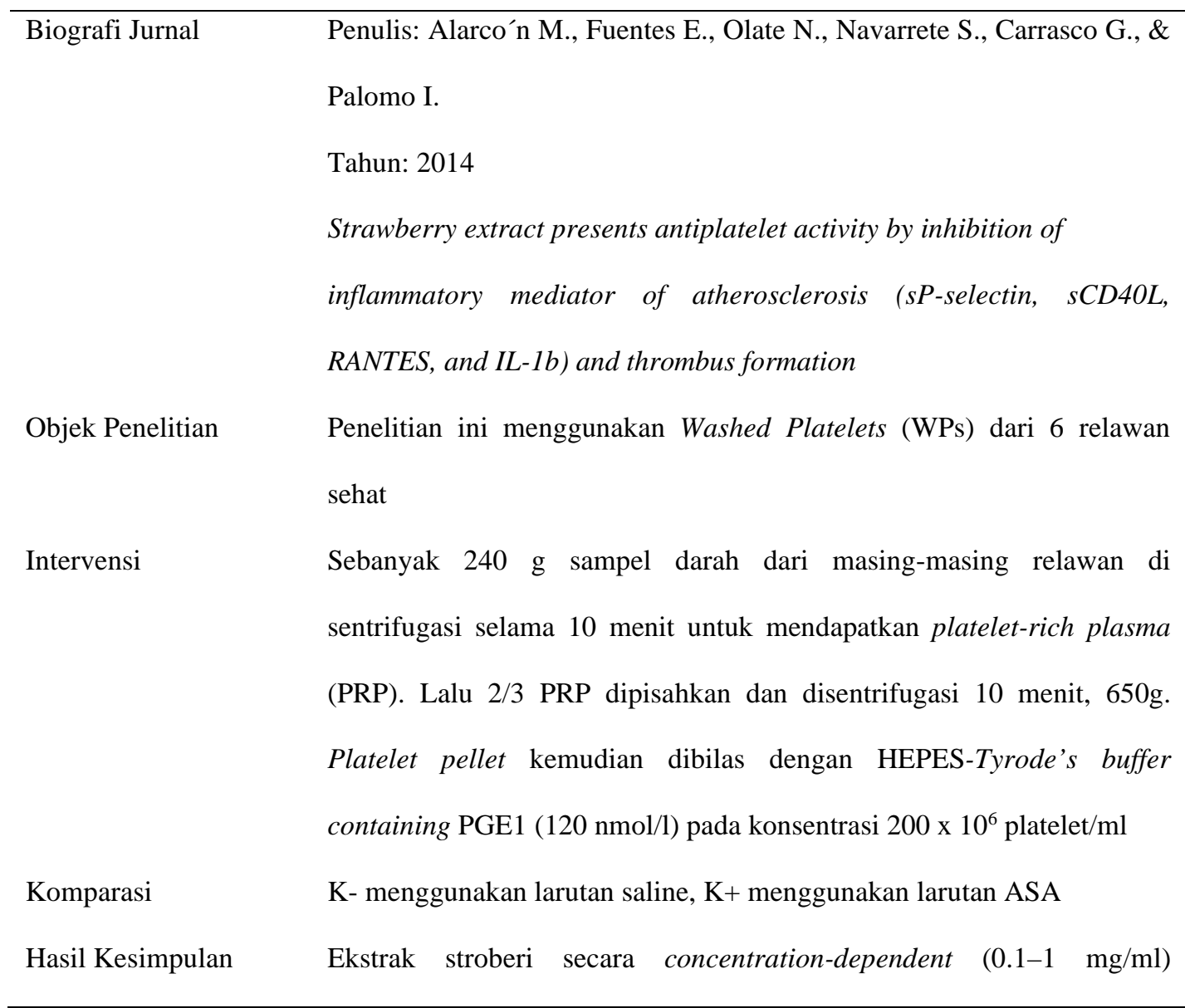


menghambat agregasi platelet terinduksi ADP dan AA. Pada konsentrasi yang sama pula, stroberi secara signifikan menurunkan jumlah sPselectin, sCD40L, RANTES, dan IL-1b sebagai mediator-mediator inflamasi.

\section{Original Article 2}

\begin{tabular}{|c|c|}
\hline \multirow[t]{4}{*}{ Biografi Jurnal } & Penulis: Bijak M, Sut A, Kosiorek A, Saluk-Bijak J, dan Golanski J \\
\hline & Tahun: 2018 \\
\hline & Dual Anticoagulant/Antiplatelet Activity of \\
\hline & Polyphenolic Grape Seeds Extract \\
\hline \multirow[t]{2}{*}{ Objek Penelitian } & Penelitian ini menggunakan PRP yang diambil dari 30 relawan sehat (15 \\
\hline & laki-laki dan 15 perempuan, dengan usia rata-rata usia $24.9 \pm 8.2$ tahun) \\
\hline \multirow[t]{5}{*}{ Intervensi } & $\begin{array}{l}\text { Sampel PRP yang didapatkan dengan cara sentrifugasi, di inkubasi } \\
\text { dengan ekstrak biji anggur selama } 15 \text { menit pada suhu } 37 \circ \mathrm{C} \text { sebelum di }\end{array}$ \\
\hline & uji. Konsentrasi final dari ekstrak dikalibrasi senyawa fenoliknya, dan \\
\hline & didapatkan 7.5 atau $15 \mu \mathrm{g}$ GAE/mL (gallic acid equivalent). Kemudian \\
\hline & dilarutkan dengan DMSO, sehingga konsentrasi final pada semua \\
\hline & sampel dan control menjadi $0.17 \%$. \\
\hline Komparasi & Kontrol menggunakan GSE dengan konsentrasi $82.7 \mathrm{U}$ \\
\hline \multirow[t]{7}{*}{ Hasil Kesimpulan } & GSE menurunkan agregasi platelet yang diinduksi ADP sebesar 7.5 \\
\hline & $\mu \mathrm{g} / \mathrm{mL}$ pada konsentrasi GSE $66.6 \mathrm{U}$, dan sebesar $15.0 \mu \mathrm{g} / \mathrm{mL}$ pada \\
\hline & konsentrasi GSE 50.5 U. Dikomparasikan dengan kontrol, dan \\
\hline & didapatkan secara signifikan $(\mathrm{p}<0.012$ dan $\mathrm{p}<0.0001)$. GSE juga \\
\hline & menurunkan indeks reaktivitas platelet, berdasarkan fosforilasi VASP: \\
\hline & $80.3 \%$ pada $7.5 \mu \mathrm{g} / \mathrm{mL}$ GSE $(\mathrm{p}<0.006)$, dan $80.8 \%$ pada GSE dengan \\
\hline & konsentrasi $15.0 \mu \mathrm{g} / \mathrm{mL}(\mathrm{p}<0.03)$ dibandingkan dengan kontrol $85.0 \%$ \\
\hline
\end{tabular}




\begin{tabular}{ll}
\hline Biografi Jurnal & Penulis: Beretta HV., Bannoud F., Insani M., Berli F., \\
& Hirschegger P, Galmarini CR., dan Cavagnaro, PF. \\
& Tahun: 2017 \\
& Relationships Between Bioactive Compound Content and \\
& the Antiplatelet and Antioxidant Activities of Six Allium \\
& Vegetable Species \\
Objek Penelitian & Penelitian ini menggunakan PRP dari darah yang diambil dari 2 relawan \\
& sehat yang tidak merokok, laki-laki 30 tahun dan perempuan 25 tahun \\
Intervensi & Dari tiap spesies, dilakukan pengulangan sebanyak 3 kali pada sampel \\
& PRP, dengan dosis awal sebanyak $5 \mu \mathrm{L}$, dan kemudian $15-50 \mu \mathrm{L}$ per Ml \\
Komparasi & K- tidak diberi perlakuan \\
Hasil Kesimpulan & Ekstrak dari bawang putih didapatkan hasil yang paling baik dalam \\
& menghambat agregasi platelet, dan diikuti oleh bawang merah dan lokio \\
& yang menghambat aggregasi platelet pada setiap dosis (p<0.05) mulai \\
& dari 5 dan $15-50 \mu \mathrm{L}$ per mL \\
& dari darah.
\end{tabular}

Original Article 4

\begin{tabular}{ll}
\hline Biografi Jurnal & Penulis: Dewi RS., Sandhiutami NMD., Raharjo S. \\
& Tahun: 2017 \\
& Efek Anti-Agregasi Platelet Ekstrak Etanol Daun Salam (Syzygium \\
& polyanthum (Wight) Walp.) pada Mencit \\
Objek Penelitian & Obyek penelitian ini adalah 25 ekor mencit jantan galur DDY usia 2-3 \\
& bulan dengan BB 25-35g, dengan 5 kelompok yang masing-masing \\
& terdiri dari 5 ekor mencit. Digunakan pula sampel darah dari vena sinus \\
& orbital yang disentrifugasi menjadi Platelet Rich Plasma (PRP) \\
Intervensi & Kelompok 1 diberikan ekstrak etanol 70\% daun salam degan dosis
\end{tabular}


150mg/kg BB. Kelompok 2 diberikan ekstrak etanol 70\% daun salam degan dosis 300mg/kg BB, dan kelompok 3 diberikan ekstrak etanol $70 \%$ daun salam degan dosis $450 \mathrm{mg} / \mathrm{kg}$ BB.

Menentukan lama perdarahan dilakukan dengan melukai ekor mencit $2 \mathrm{~cm}$ dari pangkalnya, dengan kedalaman $2 \mathrm{~mm}$. Darah yang keluar dihitung lama perdarahannya dari interval waktu tetes pertama hingga terakhir dari 5 kelompok uji. PRP $250 \mu \mathrm{L}+3 \mathrm{~mL} \mathrm{NaCl} 0,9 \%$ diukur serapan plasmanya dengan spektrofotometer $600 \mathrm{~nm}$, lalu diberikan induksi $30 \mu \mathrm{L}$ ADP $5 \mu \mathrm{M}$. Setelah diinduksi, diukur kembali dan diinkubasi 20 menit. Serapan plasma diukur dengan persentase selisih serapan plasma sebelum dan sesudah induksi. Data setelah diberikan perlakuan pada 5 kelompok uji selanjutnya dievaluasi secara statistik.

Komparasi

Hasil Kesimpulan Kelompok $\mathrm{K}+$ diberikan larutan clopidogrel dosis $75 \mathrm{mg} / \mathrm{kg}$ BB. Kelompok kontrol normal diberikan larutan aquadest dan $1 \%$ Tween 80 Ekstrak etanol $70 \%$ daun salam dapat meningkatkan lama waktu perdarahan dan koagulasi serta menurunkan serapan plasma terinduksi ADP. Dosis $450 \mathrm{mg} / \mathrm{kg}$ BB terbukti meningkatkan waktu koagulasi sebanding dengan $\mathrm{K}+$, dan meningkatkan waktu perdarahan paling lama, serta menurunkan serapan plasma terinduksi ADP, bahkan lebih efektif daripada $\mathrm{K}+$.

\section{Original Article 5}

\begin{tabular}{ll}
\hline Biografi Jurnal & Penulis: Fridayanti KD., Komariah C., Firdaus J. \\
& Tahun: 2017 \\
& Efek Ekstrak Kulit Mangga (Mangifera indica L.) Arumanis terhadap \\
& Lama Perdarahan Mencit Putih Jantan \\
Objek Penelitian & Obyek pada penelitian ini adalah 28 ekor mencit putih jantan usia 2-3
\end{tabular}


bulan dengan bobot 25-30g. Terbagi dalam 7 kelompok, yaitu kontrol negatif (K-), kontrol positif (K+), dan kelompok perlakuan 1, 2, 3, 4, dan 5 .

Intervensi

Komparasi

Hasil Kesimpulan

Original Article 6

\begin{tabular}{ll}
\hline Biografi Jurnal & Penulis: Fuentes E., Doria OF., Carrasco G., Maricán A., \\
& Santos LS., Alarcón M., dan Palomo I. \\
& Tahun: 2013 \\
& Effect of Tomato Industrial Processing on Phenolic Profile and \\
& Antiplatelet Activity \\
& Penelitian ini menggunakan PRP yang di ambil dari 2 orang relawan \\
Objek Penelitian & yang sehat (in vitro). Pengujian secara in vivo menggunakan mencit \\
& dengan strain C57BL/6
\end{tabular}

BB, dan KP 5 diberikan 16,80mg/g BB.

Hari ketujuh dilakukan uji waktu perdarahan dengan memotong ekor mencit $10 \mathrm{~mm}$ dari ujungnya dan dimasukkan ke tabung dengan normal saline. Lama perdarahan dihitung dengan stopwatch dari tetes pertama hingga berhenti menetes. Ditunggu hinga 30 menit untuk melihat jika ada re-bleeding

$\mathrm{K}$ - diberikan larutan aquadest, dan $\mathrm{K}+$ diberikan aspirin

Hasil didapatkan ekstrak kulit mangga dapat meningkatkan rerata waktu perdarahan mencit. Rata-rata waktu perdarahan terpanjang oleh KP 5 (16,80mg/g BB) dengan waktu rata-rata 1789,25 detik, sementara K+ 1496,00 detik

dengan strain C57BL/6 


\begin{tabular}{|c|c|}
\hline Intervensi & Darah disentrifugasi $240 \mathrm{~g}$ selama 10 menit menjadi PRP. 480 L PRP \\
\hline & di preinkubasi dengan $20 \mathrm{~L}$ saline, ASA $(0.3 \mathrm{mmol} / \mathrm{L})$ atau \\
\hline & ekstrak/senyawa $(1 \mathrm{mg} / \mathrm{mL}$ atau $0.5 \mathrm{mmol} / \mathrm{L})$ selama 3 menit. $20 \mathrm{~L}$ \\
\hline & agonis (ADP 8 mol/L, kolagen $1.5 \mathrm{~g} / \mathrm{mL}$, TRAP-6 $30 \mathrm{~mol} / \mathrm{L}$ atau \\
\hline & AA $1 \mathrm{mmol} / \mathrm{L})$ selama 6 menit \\
\hline Komparasi & K- tidak diberikan perlakuan \\
\hline Hasil Kesimpulan & Tomat pomace didapatkan memiliki efek yang lebih tinggi dalam \\
\hline & menghambat agregasi platelet daripada tomat segar, bahkan dikatakan \\
\hline & paling poten diantara olahan tomat yang lain dan tomat segar. \\
\hline
\end{tabular}

Original Article 7

Penulis: Gaoa P, Lia S, Liud K, Sund C, Songa S, dan Li L.
Tahun: 2018
Antiplatelet Aggregation and Antithrombotic Benefits of terpenes and
flavones from Hawthorn leaf extract isolated using activity guided
method.

Objek Penelitian

Intervensi

\section{Menggunakan PRP dari tikus}

Simplisia kering daun hawthorn (100 g) diekstraksi dengan

$75 \% \mathrm{EtOH} / \mathrm{H} 2 \mathrm{O}$ sebanyak 3 kali dibawah reflux, dan difiltrasi untuk mendapatkan ekstrak kasar (crude) sebanyak 19.6 g. Ekstrak kemudian diolah menjadi 4 fraksi. Kemudian fraksi $55 \%$ etanol dipilih untuk dilakukan subfraksi, dan didapatkan 3 sub-fraksi dari fraksi C, kemudian fraksi aktif di analisis dengan HPLC-Q-TOF MS dan teridentifikasi 25 senyawa aktif. Fraksi dan senyawa aktif dilarutkan dengan 5\% dimethyl sulphoxida (DMSO) menjadi konsentrasi akhir yaitu $0.25 \mathrm{mg} \mathrm{mL}-1$, dan tiap sampel diujikan terhadap PRP dan diinkubasi pada suhu $37{ }^{\circ} \mathrm{C}$ selama 5 menit sebelum diberikan ADP sebagai induksi. Kemampuan 
agregasi platelet dari fraksi dan senyawa terhadap PRP tikus diukur menggunakan hemacytometer. Tiap perlakuan diuji sebanyak 3 kali dan diambil nilai rata-rata.

Komparasi K- menggunakan normal saline, dan K+ menggunakan aspirin

Hasil Kesimpulan $\quad$ Fraksi elusi ethanol 55\% menunjukkan efek kuat dalam menghambat agregasi platelet (dengan inhibition rate $77.85 \pm 7.64 \%$ pada $250 \mu \mathrm{g} \mathrm{mL}-$ 1). Senyawa 7 dan 10 menunjukkan aktivitas hambatan tertinggi, yaitu $99.83 \pm 2.62 \%$ dan $89.59 \pm 3.15 \%$, pada konsentrasi $0.25 \mathrm{mg} \mathrm{mL}-1$

\section{Original Article 8}

Biografi Jurnal

Objek Penelitian

Intervensi

Komparasi

Hasil Kesimpulan

\section{Penulis: Huia F, Beibei G, Yingli Z, Xing F, Maohong B, Quan X}

Tahun: 2019

Curdione inhibits thrombin-induced platelet aggregation via regulating the AMP-activated protein kinase-vinculin/talin-integrin $\alpha \mathrm{l} \mathrm{lb} \beta 3$ sign pathway

Penelitian ini menggunakan WPs yang diambil dari relawan sehat yang selama 14 hari tidak mengkonsumsi obat-obatan apapun

Sampel darah disentrifugasi pada $800 \mathrm{rpm}$ selama 15 menit, pada suhu $25^{\circ} \mathrm{C}$, dan PRP didapatkan dari supernatant. Platelet didapatkan dari PRP yang kemudian disentrifugasi kembali pada $3000 \mathrm{rpm}$ selama 5 menit dan diberikan alprostadil. Kemudian, platelet diberikan ACD buffer dan buffer pembilas. WPs kemudian disuspensi kembali dengan Tyrode's/HEPES buffer, dan konsentrasi akhir menjadi 3×108/ml.

$\mathrm{K}+$ dengan $2 \mathrm{~g} / \mathrm{ml}$ tirofiban

Didapatkan hasil bahwa kurdion, fraksi isolat dari Curcuma aromatica Salisb dengan konsentrasi 100 M menghambat agregasi platelet yang terinduksi thrombin, dan juga menghambat pelepasan partikel alpha 
yang penting untuk aktivasi platelet terinduksi thrombin.

\section{Original Article 9}

Biografi Jurnal Penulis: Hadi FS., Setiawati Y., Khaerunnisa S.

Tahun: 2018

Uji Efek Aged Garlic Extract (Allium sativum L) terhadap Waktu

Perdarahan Mencit Putih Jantan

Objek Penelitian

Penelitian ini menggunakan 30 ekor mencit putih jantan dibagi menjadi

5 kelompok dan masing-masing terdiri dari 4 mencit $(\mathrm{K}-, \mathrm{K}+, \mathrm{P} 1, \mathrm{P} 2$,

P3)

Intervensi

P1 diberi AGE 1mg/20g BB, P2 2mg/20g BB, P3 4mg/20g BB selama

14 hari per oral

Komparasi $\quad \mathrm{K}$ - hanya diberi makan, $\mathrm{K}+$ diberi clopidogrel bisulfat dengan dosis

0,195mg 1 kali sehari

Hasil Kesimpulan Hasil didapatkan P1, P2 dan P3 tidak signifikan dalam penghambat agregasi platelet

Original Article 10

\begin{tabular}{ll}
\hline Biografi Jurnal & Penulis: Hidayati NLD., Sukma EJ. \\
& Tahun: 2015 \\
& Uji Aktivitas Antitrombosit Ekstrak Etanol Rimpang Jahe Merah \\
& (Zingiber officinale roscoe var. Sunti val.) terhadap Mencit Betina Galur \\
& Swiss Webster \\
& Penelitian ini menggunakan 20 ekor mencit betina umur 2-3 bulan \\
Objek Penelitian & dengan BB 25-35g yang dibagi menjadi 5 kelompok (K-, P1, P2, K+ \\
& asetosal, dan K+ warfarin) \\
& P1 diberi ekstrak etanol rimpang jahe merah sebanyak 4,1mg/20g BB +
\end{tabular}


PGA 1\%, P2 sebanyak 8,2/20g BB + PGA 1\%, kemudian di ukur waktu perdarahan dengan metode Duke

Komparasi

Hasil Kesimpulan

$\mathrm{K}$ - hanya diberikan suspensi PGA $1 \%, \mathrm{~K}+$ dengan asetosal diberi $0,26 \mathrm{mg} / 20 \mathrm{~g} \mathrm{BB}+\mathrm{PGA} 1 \%, \mathrm{~K}+$ warfarin diberi $0,0052 \mathrm{mg} / 20 \mathrm{~g} \mathrm{BB}+$ PGA $1 \%$

Hasil didapatkan P1 dan P2 memiliki aktivitas antiplatelet jika dibandingkan dengan K-,dan P2 lebih efektif dari P1. Bila dibandingkan dengan $\mathrm{K}+$ asetosal memiliki aktivitas yang sama

\section{Original Article 11}

Biografi Jurnal

Penulis: Idacahyati K., Fauzi DR., Lestari T.

Tahun: 2020

Pengaruh Pemberian Ekstrak Etanol Rumput Laut Merah (Gracilaria verrucosa) Terhadap Waktu Pendarahan (Bleeding Time) pada Tikus Putih Jantan Galur Wistar

Objek Penelitian Penelitian ini menggunakan 25 ekor tikus jantan galur wistar sehat yang dibagi menjadi 5 kelompok (K+, K-, P1, P2, P3)

Intervensi P1 diberi ekstrak etanol rumput laut merah sebanyak 60mg/200g BB, P2 120/200g BB, P3 240/200g BB selama 7 hari, kemudian di uji waktu perdarahan pada ekor tikus

Komparasi $\mathrm{K}+$ diberi aspirin $12,6 \mathrm{mg} / 200 \mathrm{~g} \mathrm{BB}, \mathrm{K}$ - diberi $\mathrm{NaCMC} 1 \%$

Hasil Kesimpulan K+ memberikan efek perpanjangan waktu perdarahan menjadi 198,36 detik, sedangkan P3 memperpanjang waktu perdarahan menjadi 236,8 detik

Original Article 12

Biografi Jurnal $\quad$ Penulis: Irfan M, Kwon TH, Yun BS, Park NH, dan Rhee MH


Tahun: 2018

Eisenia bicyclis (brown alga) modulates platelet function and inhibits thrombus formation via impaired P2Y12 receptor signaling pathway

Objek Penelitian

Intervensi

Komparasi

Hasil Kesimpulan
Penelitian ini menggunakan PRP dan WPs yang diambil dan disentrifugasi dari darah mencit jantan Sprague-Dawley berbobot 250$260 \mathrm{~g}$.

PRP dan WPs dipersiapkan dengan cara sentrifugasi. Diberikan 3 perlakuan dengan ekstrak Eisenia bicyclis, yaitu konsentrasi 6,25 g/ml, $12,5 \mathrm{~g} / \mathrm{ml}$, dan $25 \mathrm{~g} / \mathrm{ml}$.

K- hanya diberikan saline

Ketiga konsentrasi ekstrak Eisenia bicyclis secara signifikan dan secara dose-dependent menghambat agregasi platelet yang dinilai dengan menggunakan LTA.

\section{Original Article 13}

\begin{tabular}{ll}
\hline Biografi Jurnal & Penulis: Kartiningsih, Abdillah S., Simanjuntak P., Cyntia, Haryo \\
& Tahun: 2019 \\
& Karakterisasi Nanopartikel dan Uji Antiagregasi Platelet \\
& secara In-Vitro terhadap Ekstrak Rumput Laut Coklat (Sargassum \\
& polycystum) Hasil Hidrolisis Enzim Sellulase \\
& Obyek pada penelitian ini yaitu sampel darah yang disentrifugasi \\
Objek Penelitian & sehingga didapatkan PRP \\
& Rumput laut cokelat diberikan pada PRP dan diperiksa serapan \\
Intervensi & plasmanya. Sediaan sampel berupa ekstrak rumput laut cokelat sebelum \\
& dihidrolisis enzim (125 g/mL, $250 \mathrm{~g} / \mathrm{mL}, 500 \mathrm{~g} / \mathrm{mL})$, sesudah \\
& hidrolisis (125 g/mL, $250 \mathrm{~g} / \mathrm{mL}, 500 \mathrm{~g} / \mathrm{mL})$, dan nanopartikel ekstrak \\
& terhidrolisis enzim (125 g/mL, $250 \mathrm{~g} / \mathrm{mL}, 500 \mathrm{~g} / \mathrm{mL})$.
\end{tabular}




\begin{tabular}{|c|c|}
\hline Komparasi & $\mathrm{K}+$ dengan clopidogrel \\
\hline \multirow[t]{8}{*}{ Hasil Kesimpulan } & Hasil yang didapatkan ekstrak rumput laut tidak terhidrolisis dosis \\
\hline & 125 dapat menghambat agregasi $13,76 \%, 18,45 \%$ dosis $250 \mathrm{~g} / \mathrm{ml}$ \\
\hline & $18,45 \%$, dosis $500 \mathrm{~g} / \mathrm{ml} \mathrm{22 \%}$. Ekstrak rumput laut terhidrolisis \\
\hline & menghambat agregasi $44,83 \%$ pada dosis $125 \mathrm{~g} / \mathrm{ml}, 53,70 \%$ pada dosis \\
\hline & $250 \mathrm{~g} / \mathrm{ml}, 57,94 \%$ dengan dosis $500 \mathrm{~g} / \mathrm{ml}$. Ekstrak nanopartikel rumput \\
\hline & laut terhidrolisis enzim yaitu $64,86 \%$ pada dosis $125 \mathrm{~g} / \mathrm{ml}, 70,66 \%$ \\
\hline & dengan dosis $250 \mathrm{~g} / \mathrm{ml}, 72,93 \%$ dengan dosis $500 \mathrm{~g} / \mathrm{ml}$. Namun masih \\
\hline & lebih rendah dari $\mathrm{K}+(83,03 \%)$ \\
\hline
\end{tabular}

\section{Original Article 14}

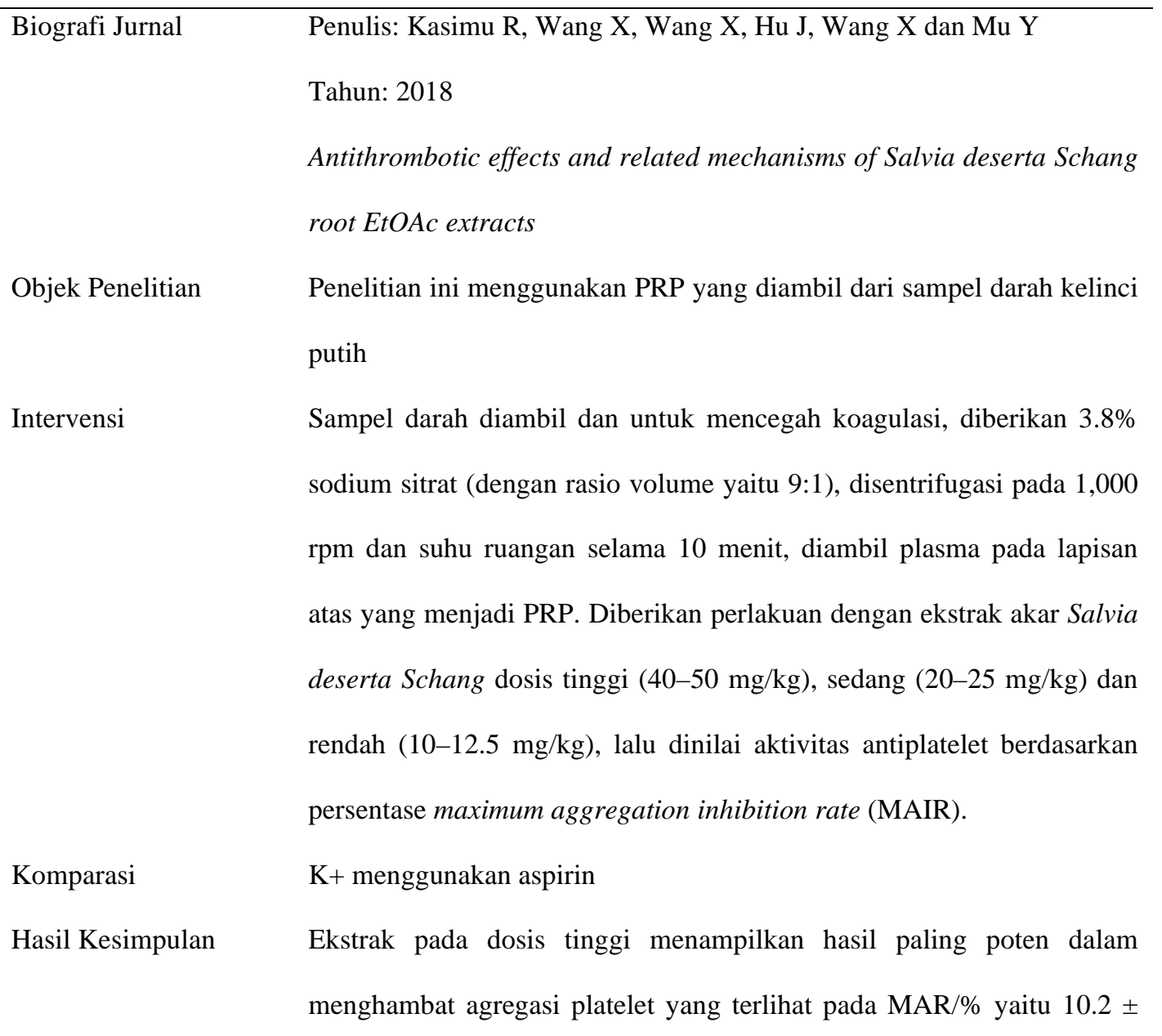


2.6, yang menyamai aktivitas aspirin berdasarkan perbandingan dengan

MAR\% pada kontrol positif

\section{Original Article 15}

Biografi Jurnal

Intervensi

Komparasi

Hasil Kesimpulan
Penulis: Kontogianni VG, Tsoumani ME, Kellici TF, Mavromoustakos

T, Gerothanassis IP, Tselepis AD, dan Tzakos AG

Tahun: 2016

Deconvoluting the dual antiplatelet activity of a plant extract

Penelitian ini menggunakan PRP dari relawan sehat dan PRP dari pasien

ACS yang mengkonsumsi terapi dual antiplatelet dengan aspirin dan ticaglerol.

PRP dari relawan sehat disentrifugasi hingga didapatkan konsentrasi akhirnya yaitu $2.5 \times 10^{8} / \mathrm{mL}$.

$\mathrm{K}+$ dengan PRP dari relawan pasien ACS yang mengkonsumsi aspirin dan ticaglerol

Efek dari senyawa dalam ekstrak daun zaitun dalam penghambatan agregasi platelet pada PRP yang diambil dari pasien dengan ACS yang mengkonsumsi terapi dual antiplatelet dengan aspirin dan ticagrelor memperlihatkan terhambatnya 2 jalur utama $(\mathrm{COX}-1$ dan reseptor P2Y12 dari ADP). Namun, masih dapat terjadi aktivasi platelet oleh thrombin melalui PAR1. Uvaol dan asam oleanolic tidak memiliki efek pada platelet yang teraktivasi oleh ADP, dimana kedua senyawa menghambat agregasi platelet oleh TRAP $(35.7 \pm 4.2 \%$ dan $33.3 \pm 2.8 \%)$. PRP dari relawan yang sehat menunjukkan spesifisitas eritrodiol dalam menghambat reseptor $\mathrm{P} 2 \mathrm{Y} 12$, uvaol dan asam oleanolic menghambat reseptor PAR1. 
Original Article 16

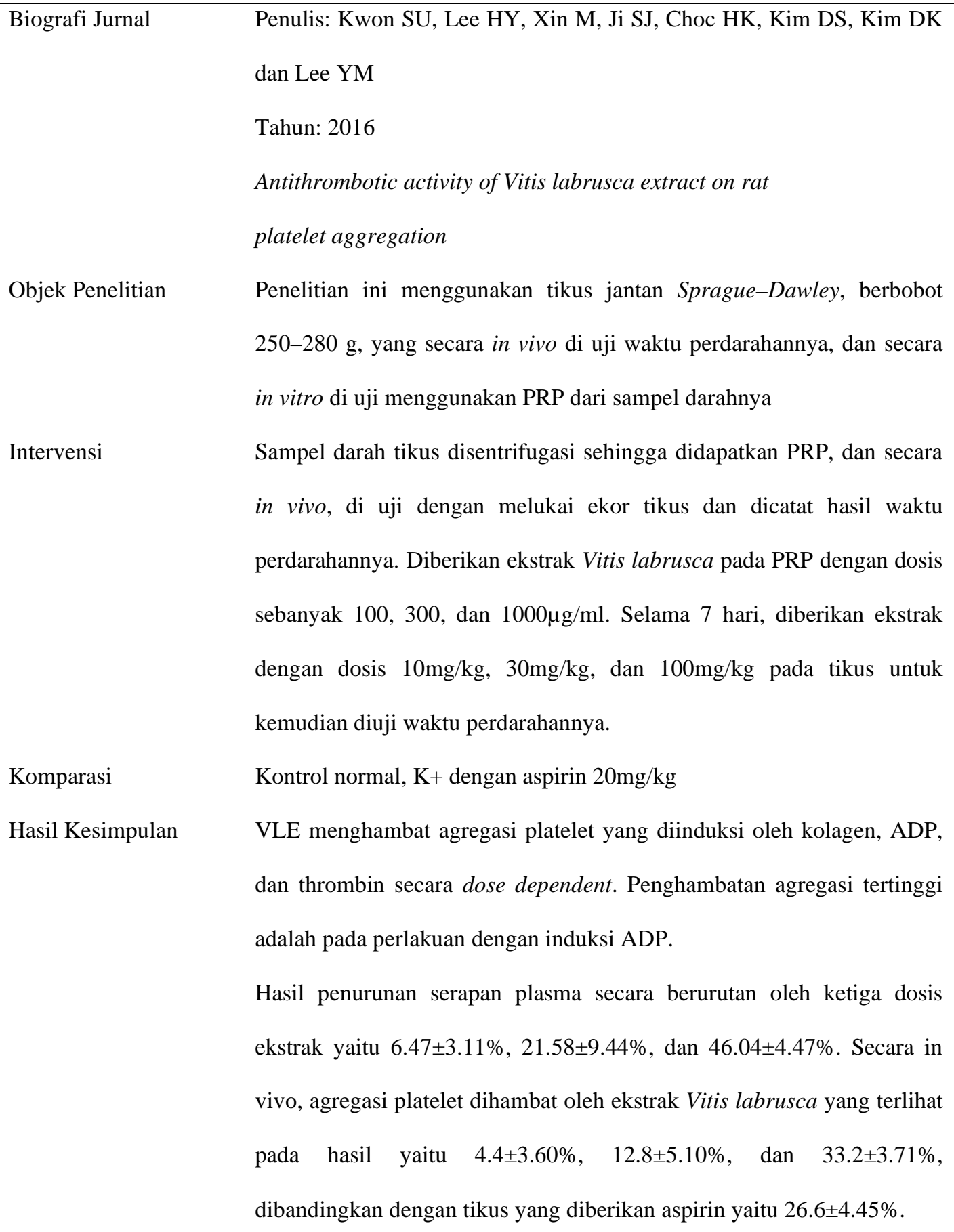

Original Article 17

Biografi Jurnal Penulis: Kim DS, Hyun DJ, Man HR, Yoon YS, Yang WK, Kim SH, 
dan Kim HK.

Tahun: 2014

Antiplatelet Activity of Morus alba Leaves Extract, Mediated via Inhibiting Granule Secretion and Blocking the Phosphorylation of Extracellular-Signal-Regulated Kinase and Akt

Objek Penelitian

Intervensi

Komparasi

Hasil Kesimpulan Menggunakan tikus Sprague-Dawley berbobot 300-350g dan diambil sampel darah dan disentrifugasi menjadi WPs WPs $\left(3 \times 10^{8} / \mathrm{mL}\right)$ dilakuka pre-inkubasi pada suhu $37 \circ \mathrm{C}$ selama $2 \mathrm{~min}$ dengan MAE maupun vehicle dan kemudian di stimulasi dengan kolagen $2.5 \mu \mathrm{g} / \mathrm{mL}$.

$\mathrm{K}+$ digunakan rivaroxaban, $5 \mathrm{mg} / \mathrm{kg} / \mathrm{hari}$

MAE $(2.5 \mu \mathrm{g} / \mathrm{mL})$ hanya menghambat agregasi platelet yang diinduksi oleh kolagen, tidak pada ADP dan thrombin.

Original Article 18

\begin{tabular}{ll}
\hline Biografi Jurnal & Penulis: Kamruzzaman SM, Endale M, Oh WJ, Park SC, Kim TH, Lee \\
& IK, Cho JY, Park HJ, Kim SK, Yun BS, dan Rhee MH Tahun: 2011 \\
& Antiplatelet Activity of Phellinus baummii Methanol Extract is Mediated \\
& by Cyclic AMP Elevation and Inhibition of Collagen-activated Integrin- \\
& ollbß3 and MAP Kinase \\
& Penelitian ini menggunakan PRP dan WPs yang di ambil dari tikus \\
Objek Penelitian & Sprague-Dawley berbobot 240-250g \\
& Darah tikus sebanyak $8 \mathrm{~mL}$ diambil dari aorta abdominal dan \\
Intervensi & disentrifugasi $170 \mathrm{~g}$ selama 7 menit. PRP dan WPs diinduksi oleh \\
& kolagen, thrombin, atau ADP pada dosis terindikasi dan agregasi yang \\
& diinduksi oleh agonis di uji aka nada atau tidaknya PMBE dalam rentang \\
& konsentrasi.
\end{tabular}




\begin{tabular}{ll}
\hline Komparasi & K- tidak diberikan perlakuan \\
Hasil Kesimpulan & PBME menghambat agregasi platelet yang diinduksi oleh thrombin, \\
& kolagen, dan ADP. PBME juga menekan sekresi ATP, mobilitas $\mathrm{Ca}^{2+}$, \\
& dan pengikatan fibrinogen
\end{tabular}

Original Article 19

Biografi Jurnal Penulis: Lee JH, Kim M, Chang KH, Hong CY, Na CS, Dong MS, Lee D, dan Lee MY

Tahun: 2014

Antiplatelet Effects of Rhus verniciflua Stokes Heartwood and Its Active Constituents—Fisetin, Butein, and Sulfuretin—in Rats

Objek Penelitian Penelitian ini menggunakan PRP dan Washed Platelets (WPs) yang diambil melalui aorta abdominal dari Tikus Sprague-Dawley berusia 56 minggu dan berbobot 130-150g yang juga digunakan untuk menguji trombosis arteri pada arteri femoralis kanan tikus

Intervensi Pada penelitian in vitro, menggunakan four-chanelled aggregometer dan PRP di sentrifugasi sebanyak 250g selama 15 menit. Kemudian platelet disentrifugasi 500g selama 10 menit dan dibilas satu kali dengan solusio buffer $\left(140 \mathrm{mM} \mathrm{NaCl}, 2,5 \mathrm{mM} \mathrm{KCl}, 1 \mathrm{mM} \mathrm{MgCl} 2,0,5 \mathrm{mM} \mathrm{Na}_{2} \mathrm{HPO}_{4}\right.$, $10 \mathrm{mM} \mathrm{NaHCO}_{3}, 1 \mathrm{mM} \mathrm{CaCl}_{2}, 0,55 \mathrm{mM}$ glukosa, $22 \mathrm{mM}$ trisodium sitrat, dan $0,3 \%$ bovine serum albumin) dengan suspensi dan sentrifugasi. WPs didapatkan dari sentrifugasi ulang dengan suspensi solusio buffer. Agregasi platelet di induksi oleh kolagen $2,5 \mathrm{ug} / \mathrm{mL}$, trombin 0,12 0,14U/mL, dan ADP 16uM.

Pengujian dengan ERK dan aktivasi p38 diukur dengan analisis konvensional western blot dengan antibodi fosfospesifik. Untuk uji antiplatelet secara in vivo, tikus diberikan ekstrak RVS, fisetin selama 7 
hari. Setelah 90 menit, tikus diberi anastesi dan arteri femoralis dipotong sepanjang 10mm, lalu diletakkan pada ultrasonic flowprobe MA0,7PSB dan dihubungkan dengan TS420 perivascular flowmeter untuk memonitor tetesan darah.

Komparasi

Hasil Kesimpulan
Pada in vivo, $\mathrm{K}+$ clopidogrel injeksi intraperitoneal sebanyak $30 \mathrm{mg} / \mathrm{kg}$ BB. Pada ERK dan aktivasi p38, K+ dengan U0126 dan SB203580.

Efek antiplatelet pada fraksi EtOAc (menjadi F5, F6 dan F9) efektif pada konsentrasi 1mg/mL. subfraksi F5-7, dan F6-8 juga didapatkan efek antiplatelet. Tiga fraksi (F9, F5-7, F6-8) menghasilkan fisetin, butein, dan sulfuretin yang menunjukkan efek relatif lebih tinggi pada IC50 value oleh agregasi yang terinduksi trombin.

\section{Original Article 20}

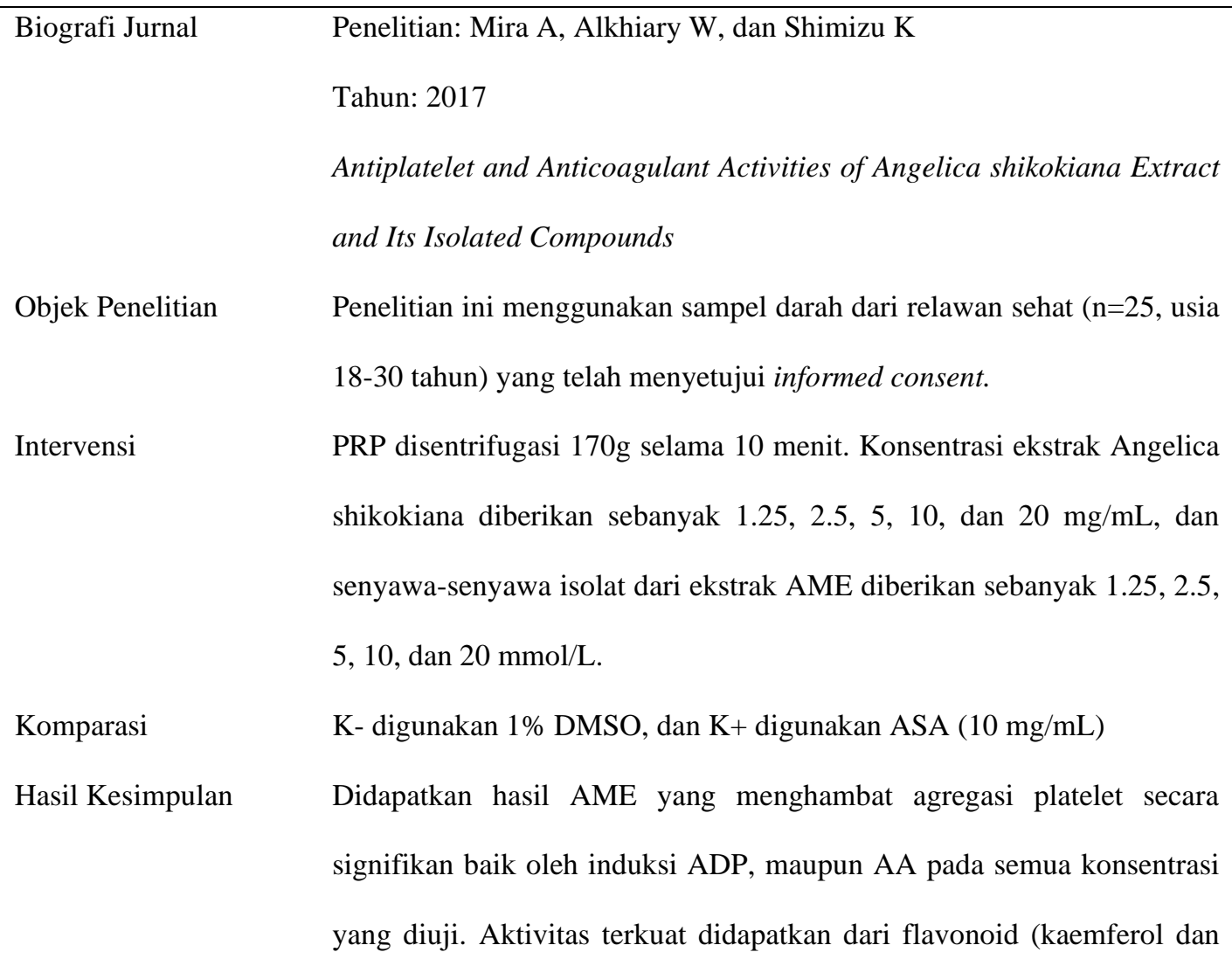


kuercetin). Luteolin, kaempferol glucoside, dan rutinoside secara

signifikan menghambat agregasi yang diinduksi oleh ADP dan AA pada

konsentrasi lebih tinggi, yaitu 5 dan $10 \mathrm{mmol} / \mathrm{L}$.

\section{Original Article 21}

Biografi Jurnal

Intervensi

Komparasi

Hasil Kesimpulan
Penulis: Magdalena S., Yuwono B., Dharmayanti AWS.

Tahun: 2015

Pengaruh Daun Katuk (Sauropus androgynus (L.) Merr.) terhadap Waktu Perdarahan (Bleeding Time) pada Tikus Wistar Jantan sebagai Alternatif Obat Antitrombotik

Obyek penelitian ini adalah 24 ekor tikus Wistar jantan sehat berusia 2-3 bulan, BB 150-200g yang dibagi menjadi 4 kelompok (K-, K+, P1, dan P2)

Perlakuan dilakukan 8 hari dengan cara sondasi lambung. Tomat kelompok P1 diberi 4,5mg/g BB ekstrak daun katuk dan P2 diberi $2,25 \mathrm{mg} / \mathrm{g}$ BB. Setelah perlakuan, ekor tikus dilukai $0,5 \mathrm{~cm}$ dari ujung dan perdarahan diteteskan di kertas whatman setiap 30 detik hingga terhentinya

$\mathrm{K}+$ diberi aspirin 5,85mg 3mL, $\mathrm{K}$ - diberi aquadest $2 \mathrm{~mL}$

$\mathrm{K}+$ meningkatkan waktu rerata perdarahan paling tinggi. P1 memperlihatkan efek perpanjangan yang kurang lebih sama dengan $\mathrm{K}+$ $(195+-16,432)$

Original Article 22

Biografi Jurnal Penulis: Ningsih DSL, Mulqie L, Hazar S

Tahun: 2017

Uji Aktivitas Antiagregasi Platelet Ekstrak Etanol Daun Tempuyung 
(Sonchus arvensis L.) pada Mencit Swiss Webster Jantan

Objek Penelitian

Intervensi

Komparasi

Hasil Kesimpulan

Penelitian ini menggunakan 25 ekor mencit jantan yang terbagi menjadi

5 kelompok (K-, K+, P1, P2, P3)

Sebelum diberikan perlakuan, waktu perdarahan mencit di uji terlebih

dahulu. P1 diberikan ekstrak etanol daun tempuyung sebanyak $50 \mathrm{mg} / \mathrm{kg}$

BB, P2 diberikan sebanyak 100mg/kg BB, dan P3 diberikan 200mg/kg

BB, kemudian dilakukan uji waktu perdarahan pada hari ke-7, 14, 21, dan 28

$\mathrm{K}$ - diberikan $\mathrm{CMC}-\mathrm{Na}$ 0,5\%, dan $\mathrm{K}+$ diberikan aspirin dengan dosis $13 \mathrm{mg} / \mathrm{kg} \mathrm{BB}$

P1 didapatkan nilai signifikan $0,02 \quad(\mathrm{p}<0,05)$ dalam memperpanjang waktu perdarahan mencit

\section{Original Article 23}

Biografi Jurnal
Tahun: 2017
Pengaruh Cara Pengolahan Bawang Putih (Allium sativum) Terhadap
Efek Antitrombotik Pada Mencit
Pada penelitian ini digunakan mencit sehat galur Swiss-Webster berusia
3-6 bulan, dengan BB 25-35g. Dikelompokkan dalam 8 kelompok
(kontrol negatif, positif, dan P1 hingga P6) yang masing-masing terdiri
dari 5 ekor mencit.
Mencit diaklimatisasi selama 7 hari sebelum diberi intervensi. Tiap
kelompok mendapat perlakuan 0,25ml tiap hari, baik dengan K-, K+,
Intervensi
bawang putih mentah dosis tinggi, bawang putih mentah dosis rendah,
bawang putih goreng dosis tinggi, bawang putih goreng dosis rendah
selama 1 bulan, kemudian di uji lama perdarahan dengan metode Duke.




\begin{tabular}{ll}
\hline Komparasi & K- larutan CMC 1\%, K+ larutan asetosal \\
Hasil Kesimpulan & Hasil dengan uji Post Hoc, ekstrak bawang putih mentah dosis tinggi \\
& maupun rendah tidak signifikan $(\mathrm{P}>0,05)$. Sementara ekstrak bawang \\
& putih yang direbus dan digoreng memberi efek pemendekan waktu \\
& perdarahan.
\end{tabular}

Original Article 24

\begin{tabular}{|c|c|}
\hline \multirow[t]{3}{*}{ Biografi Jurnal } & Penulis: Putri RF., Ulfa EU., Riyanti R. \\
\hline & Tahun: 2014 \\
\hline & $\begin{array}{l}\text { Uji Aktivitas Antiplatelet Ekstrak Etanol Kubis Merah (Brassica } \\
\text { oleracea var. capitata L.) }\end{array}$ \\
\hline Objek Penelitian & $\begin{array}{l}\text { Penelitian ini menggunakan mencit jantan galur Balb-C usia 2-3 bulan, } \\
\text { BB 20-30g dan dibagi menjadi } 5 \text { kelompok K-, K+, P1, P2, P3) }\end{array}$ \\
\hline Intervensi & $\begin{array}{l}\text { P1 diberikan ekstrak etanol kubis merah dengan dosis } 9.69 \mathrm{mg} / \mathrm{kg} \mathrm{BB}, \mathrm{P} 2 \\
\text { dengan dosis } 19,38 \mathrm{mg} / \mathrm{kg} \mathrm{BB} \text {, dan } \mathrm{P} 3 \text { dengan dosis } 38,76 \mathrm{mg} / \mathrm{kg} \mathrm{BB} \\
\text { yang diberikan peroral } 1 \mathrm{kali} \text { sehari selama } 8 \text { hari, kemudian di uji } \\
\text { waktu perdarahannya dengan melukai ekor mencit } 2 \mathrm{~cm} \text { dari pangkalnya } \\
\text { dan kedalaman maksimal } 2 \mathrm{~mm} \text {, kemudian darah diserap dengan kertas } \\
\text { saring, dihitung interval tetesan pertama hingga berakhir }\end{array}$ \\
\hline Komparasi & K-dengan CMC Na $1 \%, \mathrm{~K}+$ dengan acetosal $50 \mathrm{mg} / \mathrm{kg} \mathrm{BB}$ \\
\hline Hasil Kesimpulan & $\begin{array}{l}\text { Didapatkan P3 yang meningkatkan waktu tertinggi dibandingkan P1 dan } \\
\text { P2, sebesar } 113+-12 \% \text {, sebanding bahkan lebih efektif daripada } \mathrm{K}+\end{array}$ \\
\hline
\end{tabular}

Original Article 25

Biografi Jurnal $\quad$ Penulis: Park ES, Lim Y, Lee S, Kwon BM, Hwan SY, Jin TH, Yeo PY
Tahun: 2011
Antiplatelet activity of Obovatol, a Biphenolic Component of Magnolia

Antiplatelet activity of Obovatol, a Biphenolic Component of Magnolia 
obovata, in Rat Arterial Thrombosis and Rabbit Platelet Agreggation

Objek Penelitian

Intervensi

Komparasi

Hasil Kesimpulan
Penelitian ini secara in vivo menggunakan tikus jantan Sprague-Dawley, dan uji thrombosis dimodifikasi dengan $\mathrm{FeCl}_{3}$, secara ex vivo menggunakan PRP dari tikus jantan Sprague-Dawley. PRP juga diambil dari arteri telinga kelinci.

Obovatol diberikan dengan dosis 240-260g tiap hari dengan CMC 50 dan $100 \mathrm{mg} / \mathrm{kg}$ untuk 3 hari. Setelah di anastesi dengan fenobarbital sodium (60mg/kg BB intraperitoneal), dipotong arteri karotis kanan (1mm) kemudian dinilai tetesan darahnya pada Doppler flow probe

K- DMSO 0,5\%, K+ dengan aspirin 50uM

In vivo: didapatkan waktu oklusi secara signifikan mengalami pemanjangan waktu menjadi $22,4 \pm 5,4$ dan $31,6 \pm 6,4$ menit pada dosis 50 dan $100 \mathrm{mg} / \mathrm{kg} \mathrm{BB}(\mathrm{P}<0,01 ; \mathrm{n}=10)$. Ex vivo: obovatol secara signifikan menghambat agregasi platelet yang diinduksi oleh kolagen menjadi $39,5 \pm 4,5$ dan $94,9 \pm 1,6 \%(\mathrm{P}<0,01 ; \mathrm{n}=7)$ pada dosis 50 dan $100 \mathrm{mg} / \mathrm{kg}$ BB. Namun, obovatol gagal dalam menghambat agregasi platelet yang diinduksi oleh ADP.

In vitro pada PRP dari kelinci didapatkan hasil obovatol menghambat agregasi platelet yang diinduksi oleh kolagen $(10 \mathrm{ug} / \mathrm{mL})$ dan AA

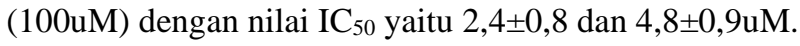

\section{Original Article 26}

\begin{tabular}{ll}
\hline Biografi Jurnal & Penulis: Santoso P \\
& Tahun: 2015 \\
& Uji Aktivitas Antiplatelet Ekstrak Daun Lempeni (Ardisia Humilis Vahl) \\
& Pada Mencit \\
Objek Penelitian & Penelitian ini menggunakan 20 ekor mencit jantan galur murni sehat,
\end{tabular}


usia 2-3 bulan, BB 21-35g yang dibagi menjadi 4 kelompok dengan masing-masing terdiri dari 5 ekor mencit $(\mathrm{K}+, \mathrm{P} 1, \mathrm{P} 2$ dan $\mathrm{P} 3)$

Intervensi

Komparasi

Hasil Kesimpulan

P1 diberi ekstrak daun lemperni sebanyak 100mg/kg BB, P2 200mg/kg BB, P3 300mg/kg BB per oral selama 7 hari, kemudian dilakukan uji waktu perdarahan

$\mathrm{K}+$ diberikan acetosal 30mg/kg BB

Hasil uji Anova dan Paired sample t test didapatkan bahwa ekstrak daun lempeni signifikan dalam memberikan efek antiplatelet, terlihat juga dari perpanjangan waktu pada P3 dari 83 detik menjadi 242,2 detik

\section{Original Article 27}

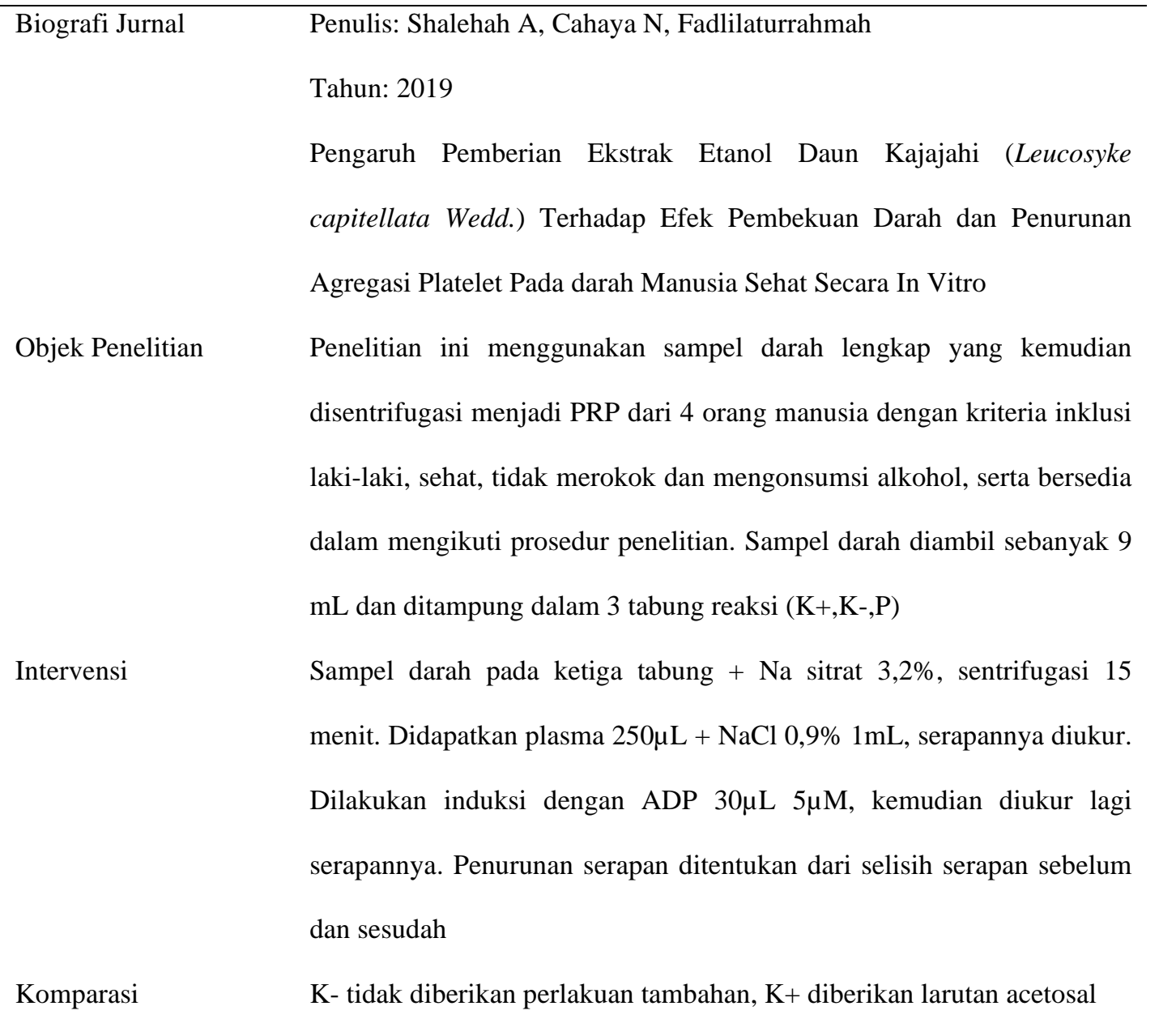


Hasil Kesimpulan

Ekstrak etanol daun kajajahi dapat menghambat agregasi platelet

$(\mathrm{p}=0,086)$, namun tidak ada perbedaan bermakna dengan $\mathrm{K}+$

\section{Original Article 28}

Biografi Jurnal

Objek Penelitian
Intervensi

Komparasi

Hasil Kesimpulan
Penulis: I Gusti Agung Ayu Kusuma Wardani, Ni Nyoman Wahyu

Udayani

Tahun: 2017

Pengaruh Pemberian Ekstrak Etanol Daun Belimbing Wuluh (Averrhoa bilimbi l.) Terhadap Waktu Perdarahan dan Waktu Koagulasi Pada Mencit Jantan (Mus musculus l.)

Obyek penelitian ini adalah mencit jantan sehat berusia 8-12 minggu dengan BB 17-40g. Kelompok uji dibagi menjadi 4 kelompok (K-, K+, P1 dan P2)

Semua kelompok uji diberikan perlakuan per oral selama 7 hari sebanyak 0,5mL. Dosis ekstrak daun belimbing wuluh pada P1 diberikan 200mg/kg BB,dan P2 400mg/kg BB. Uji waktu perdarahan dengan melukai ekor mencit $2 \mathrm{~cm}$ dari ujungnya sepanjang $2 \mathrm{~mm}$. Hasil didapatkan dari nterval waktu tetes pertama hingga berhentinya $\mathrm{K}+$ diberi acetosal $(0,27 \mathrm{mg} / 26 \mathrm{~g} \mathrm{BB}), \mathrm{K}$ - diberi aquadest $\mathrm{K}+$ menunjukkan peningkatan waktu perdarahan dari 62,1 detik menjadi 126 detik, dan P2 dari 55,1 detik menjadi 81 detik. Ekstrak etanol daun katuk dapat memperpanjang waktu perdarahan, namun lebih efektif acetosal

Original Article 29

Biografi Jurnal Penulis: Yang WK, Lee JJ, Sung YY, Kim DS, Myung CS, dan Kim HK

Tahun: 2013 
Extract of Ulmus macrocarpa Hance prevents thrombus formation through antiplatelet activity

Objek Penelitian

Intervensi

Komparasi

Hasil Kesimpulan

Penelitian ini secara in vitro menggunakan PRP, secara in vivo menggunakan trombosis arteri pada tikus jantan Sprague-Dawely berbobot $240-250 \mathrm{~g}$

PRP disentrifugasi 180 x g selama 10 menit, ekor tikus di potong dan dilihat perdarahan arteri karotis kanan

$\mathrm{K}+$ dengan aspirin $20 \mathrm{mg} / \mathrm{kg} \mathrm{BB}$

UME secara signifikan menghambat pembentukan thrombus arteri secara in vivo, dan juga menunjukkan potensi sebagai antiplatelet karena menghambat agregasi yang diinduksi oleh ADP dan kolagen

\section{Original Article 30}

\begin{tabular}{ll}
\hline Biografi Jurnal & Penulis: Yasa IWPS, Astuti KW, Aman IGM \\
& Tahun: 2012 \\
& Acetosal, Buah Mengkudu (Morinda citrifolia l.) dan Waktu Perdarahan \\
Objek Penelitian & Obyek dalam penelitian ini menggunakan mencit putih jantan yang \\
& dipilih secara acak dari 30 mencit putih jantan dewasa yang sehat, \\
& berumur $8-12$ minggu, dengan BB 20-22gr. Mencit di observasi selama \\
& 1 minggu, dan mencit yang tidak mau makan dikeluarkan dari \\
& kelompok. Didapatkan sisa 24 ekor mencit jantan. Kemudian mencit \\
& dibagi menjadi 3 kelompok perlakuan yang masing-masing terdiri dari 8 \\
& ekor mencit. \\
& Sebelum diberikan intervensi, semua mencit di uji waktu perdarahan \\
& dengan cara melukai ekor mencit $2 \mathrm{~cm}$ dari ujung ekor sepanjang 2mm, \\
Intervensi & dengan kedalaman 1mm. Setiap kelompok diberikan perlakuan selama 7 \\
& hari, 1 hari 1 kali.
\end{tabular}


Kelompok 1 diberikan acetosal dengan dosis $40 \mathrm{mg} / \mathrm{kgBB}$, per oral 0,5mL. Kelompok 2 diberikan ekstrak etanol buah mengkudu dengan dosis $100 \mathrm{mg} / \mathrm{kgBB}$, per oral, 0,5mL. Kelompok 3 diberikan gabungan acetosal $40 \mathrm{mg} / \mathrm{kgBB}$ dan ekstrak etanol buah mengkudu $100 \mathrm{mg} / \mathrm{kgBB}$, peroral $0,25 \mathrm{~mL}$ larutan acetosal, $0,25 \mathrm{~mL}$ larutan ekstrak etanol buah mengkudu. Setelah 7 hari, dilakukan uji lama waktu perdarahan mencit.

Komparasi

Hasil Kesimpulan
Kontrol positif adalah kelompok perlakuan 1, yaitu diberi larutan acetosal $40 \mathrm{mg} / \mathrm{kg}$ BB peroral sebanyak $0,5 \mathrm{~mL}$.

Kelompok 1 mengalami peningkatan waktu perdarahan, kelompok 2 juga mengalami peningkatan waktu perdarahan. Kelompok 3 mengalami peningkatan waktu perdarahan paling lama. Hasil yang didapatkan dengan uji one way ANOVA menunjukkan signifikansi perbedaan dari ketiga kelompok setelah diberi intervensi $(\mathrm{p}=0,006)$. Sebagai kesimpulan, gabungan acetosal dan ekstrak etanol buah mengkudu lebih berpotensi memperpanjang waktu perdarahan daripada acetosal dosis tunggal.

\section{Original Article 31}

Biografi Jurnal
Tahun: 2018
Characterization of active antiplatelet chemical compositions of edible
Citrus limon through ultra-performance liquid chromatography single
quadrupole mass spectrometry-based chemometrics
Penelitian ini menggunakan PRP dan WPs dari kelinci yang sehat dan
Objek Penelitian
berbobot (2,2 $\pm 0,6$ kg)
THR (0.25 U/mL), ADP (10 M), AA (0.205 M) dan U46619 (0.89
M) 184 dilarutkan dalam larutan saline $0.9 \%$ sebagai induksi.




\begin{tabular}{ll}
\hline Komparasi & K- dengan menggunakan ranitidin, K+ dengan menggunakan tirofiban \\
Hasil Kesimpulan & Lemon crude ethanol extract (LEE) dapat menghambat agregasi platelet \\
& yang diinduksi oleh THR, ADP, dan AA dalam konsentrasi yang relatif \\
& rendah $(1,0 \mathrm{mg} / \mathrm{mL})$
\end{tabular}

Original Article 32

Biografi Jurnal Zhao X, Guo F, Hu J, Zhang L, Xue C, Zhang Z, Li B

Tahun: 2016

Antithrombotic activity of oral administered low molecular weight fucoidan from Laminaria Japonica

Objek Penelitian Penelitian ini secara in vitro menggunakan PRP yang diambil dari tikus Wistar jantan berbobot 280-300 g, dan secara in vivo dengan perlukaan pada ekor mencit

Intervensi

PRP dibuat dengan cara sentrifugasi $47 \times \mathrm{g}$ selama 10 menit. Digunakan trombin $(60 \mathrm{U} / \mathrm{mL})$ sebagai penginduksi agregasi platelet. Perlakuan pada $\mathrm{K}+$ diberikan aspirin secara oral sebanyak $20 \mathrm{mg} / \mathrm{kgBB}$, kelompok perlakuan masing-masing diberi MMW dan LMW fucoidan (400 dan $800 \mathrm{mg} / \mathrm{kgBB}$ ) setiap hari

Komparasi $\mathrm{K}+$ diberikan aspirin secara oral $\mathrm{K}$ - hanya diberikan aquadest

Hasil Kesimpulan Senyawa fucose pada tikus yang diberikan low molecular weight (LMW) fucoidan memperlihatkan absorbsi dan bioavailabilitas yang jauh lebih tinggi daripada MMW secara in vivo dan menghambat agregasi platelet secara signifikan. 


\section{PEMBAHASAN}

\section{Uji Aktivitas Antiplatelet}

Pada 32 literatur yang ditelaah, sebanyak 30 jurnal menyatakan hasil yang signifikan memiliki aktivitas antiplatelet, sementara 2 diantaranya tidak signifikan dalam menghambat agregasi platelet. Ekstrak yang memiliki aktivitas antiplatelet adalah ekstrak tomat dengan senyawa aktif fenolik khususnya flavonon dan flavonol dan fraksinya asam klorogenik, asam kafeat, asam p-kumarin, asam ferulat. ${ }^{14}$ Ekstrak Magnolia obovata dengan kandungan senyawa aktif bifenolik, dan fraksinya obovatol, monolol, honokiol. ${ }^{15}$ Ekstrak daun Hawthorn (Crataegus pinnatifida Bge.) dengan kandungan senyawa flavonoid, fenolik, triterpena, flavonoid glikosida, terpenoid, lignan dan fraksinya yang terdiri dari 17 terpenoid, 1 lignan, 2 fenolik, 5 flavon glikosida. ${ }^{16}$ Ekstrak daun salam (Syzygium polyanthum (Wight) Walp.) yang mengandung flavonoid kuersetin, minyak atsiri eugenol. ${ }^{17}$ Ekstrak rimpang jahe merah (Zingiber officinale Roscoe var. sunti Val.) dengan senyawa aktif flavonoid, polifenol, monoterpen, seskuiterpen. ${ }^{18}$ Ekstrak kubis merah (Brassica oleracea var. capitata L.) yang mengandung flavonoid dan glikosida isotianat. ${ }^{19}$ Ekstrak buah mengkudu (Morinda citrifolia L.) dengan senyawa fenolik, dan fraksinya yaitu kumarin. ${ }^{20}$ Ekstrak rumput laut merah (Gracilaria verrucosa) dengan senyawa aktif flavonoid. ${ }^{21}$ Ekstrak kulit mangga (Mangifera indica L.) yang mengandung flavonoid kuersetin dan katekin, asam fenol, karotenoid, mangiferin. ${ }^{22}$ Ekstrak daun belimbing wuluh (Averrhoa bilimbi L.) dengan senyawa aktif flavonoid, triterpen, saponin, tanin. ${ }^{23}$ Ekstrak daun lempeni (Ardisia humilis Vahl) yang mengandung triterpenoid $\alpha$-amyrin $\quad$ dan $\beta$-amyrin. ${ }^{24}$ Ekstrak daun kajajahi (Leucosyke capitellata Wedd.) dengan senyawa flavonoid, tannin, saponin. $^{25}$ Ekstrak rumput laut coklat (Sargassum polycystum) yang mengandung polisakarida sulfat, yaitu fucoidan. ${ }^{26}$ Ekstrak Angelica shikokiana yang mengandung flavonoid dan metabolitnya serta kumarin, dan fraksinya isoepoxypteryxin, isopteryxin, hyuganin E, kuersetin, luteolin, kaempferol, kaempferol-3-O-glucosida, kaempferol-3-Orutinosida. ${ }^{27}$ Ekstrak Phellinus baumii yang mengandung polisakarida, triterpenoid. ${ }^{28}$ Ekstrak Eisenia bicyclis yang mengandung 
senyawa tannin, dan fraksinya 6,6'-bieckol, 6,8'-bieckol, 8,8'-bieckol, dieckol, phlorofucofuroeckol-A. ${ }^{29}$ Ekstrak daun tempuyung (Sonchus arvensis L.) yang mengandung flavonoid kaempferol, fenolik, kumarin skopoletin, glikosida apigenin dan luteolin. $^{30}$ Ekstrak Morus alba yang mengandung flavonoid, fenolik, glikosida, dan fraksinya kuersetin glikosida yaitu rutin dan isokuersetin. ${ }^{31}$ Ekstrak Salvia deserta yang mengandung terpenoid dan fraksinya horminon, 7-O-acetylhormion, 6,7dehydeoroyleanone. ${ }^{32}$ Ekstrak Vitis labrusca dengan senyawa flavonoid, fenolik dan fraksinya kuersetin, isorhamnetin, rutin. ${ }^{33}$ Ekstrak dari 6 spesies Allium (A. серa, A. ascalonicum, A. sativum L., A. porrum, A. schoenopranosum) yang komponen senyawa dengan aktivitas antiplateletnya antara lain flavonoid, fenolik, organosulfur dan fraksinya katekin, epigallocatechin gallate (EGCg), epicatechin gallate (ECg), epigallocatechin (EGC), rutin, myrisetin, kuersetin, kaempferol, asam klorogenik, asam kumarin, asam Ferulat, asam kafeat, allisin (thiosulfinat). ${ }^{34}$ Ekstrak Rhus vernicflua yang mengandung flavonoid dan fraksinya sulfuretin, fisetin, butein. ${ }^{35}$ Ekstrak daun zaitun (Olea europaea L.) yang mengandung triterpenoid, dan fraksinya eritrodiol, uvaol, asam oleanolat. ${ }^{36}$ Ekstrak Ulmus macrocarpa yang mengandung senyawa fenolik dan fraksinya katekin, epikatekin. ${ }^{37}$ Ekstrak Citrus limon yang mengandung flavonoid, fenolik, terpenoid, kumarin, dan fraksinya oxypeucedanin hydrate, diosmin, limetin. ${ }^{38}$ Ekstrak stroberi yang mengandung flavonoid. ${ }^{39}$ Ekstrak Curcuma aromatica Salisb. yang mengandung seskuiterpen dan fraksinya kuordion. ${ }^{40}$ Ekstrak Laminaria japonica yang mengandung monosakarida, polisakarida sulfat yaitu fukoidan dan fraksinya galaktosa, rhamnosa, glukosa, mannosa, asam glucuronik, galaktosamin, glukosamin. ${ }^{41}$

Sedangkan, hasil yang didapatkan tidak signifikan dalam menghambat agregasi platelet adalah Aged Garlic Extract (AGE) yang mengandung S-allylcysteine (SAC), dan bawang putih (Allium sativum L.) yang mengandung allicin. Kedua penelitian ini sama-sama menggunakan ekstrak bawang putih, namun dengan cara pengolahan berbeda, dan keduanya mendapatkan hasil tidak signifikan. Jurnal terkait menyatakan bahwa hal tersebut dikarenakan senyawa aktif 
yang terkandung dalam bawang putih yaitu S-allylcysteine (SAC) dan allicin bersifat non-dose dependent. Namun, hal tersebut dapat pula disebabkan oleh cara pengolahan dengan suhu panas (rebus dan goreng) pada ekstrak bawang putih yang mengakibatkan senyawa aktif dalam ekstrak bawang putih kehilangan aktivitasnya. ${ }^{13,42}$

Namun, perlu diketahui bahwa hasil yang menyatakan tidak signifikan memiliki aktivitas antiplatelet adalah hasil dari uji aktivitas antiplatelet yang dilakukan hanya sampai pada tahap ekstrak. Sementara, senyawa-senyawa aktif yang telah sampai pada tahap fraksinasi dari jurnal yang ditelaah menyatakan hasil yang signifikan dalam menghambat agregasi platelet, senyawa-senyawa tersebut secara spesifik telah diketahui strukturnya, dan menunjukkan bahwa senyawa yang dituju dalam bentuk fraksi tersebut telah mampu tersari maksimal. ${ }^{38}$

Metode uji aktivitas antiplatelet yang paling unggul dan masih menjadi gold standard hingga saat ini adalah metode in vitro dengan Light transmission aggregometry (LTA). Selain dapat menilai penghambatan agregasi platelet melalui transimisi cahaya, LTA juga dapat mendeteksi adanya perubahan bentuk pada platelet yang teraktivasi, adanya agregasi tahap sekunder, maupun deagregasi platelet. ${ }^{43}$ Sehingga dapat terlihat pada perbandingan jumlah banyaknya penelitian yang menggunakan metode in vitro daripada metode in vivo. Namun, uji aktivitas antiplatelet dengan LTA dapat memakan waktu yang banyak, membutuhkan alat dan laboratorium yang memadai serta teknik penggunaannya cukup rumit sehingga harus dilakukan oleh peneliti yang berpengalaman. Jurnal yang menggunakan pengujian antiplatelet dengan metode in vivo saja yaitu ekstrak buah mengkudu, kulit mangga, pengaruh cara pengolahan bawang putih, daun katuk, daun belimbing wuluh, rumput laut merah, daun lempeni, kubis merah, rimpang jahe merah, daun tempuyung, dan aged garlic extract (AGE). Hal ini kemungkinan disebabkan oleh masih kurangnya fasilitas dan tempat yang memadai untuk dilakukannya uji aktivitas antiplatelet dengan metode in vitro, khususnya dengan LTA. Dari jurnal yang ditelaah, 2 diantaranya menyatakan hasil yang tidak signifikan dalam menghambat agregasi platelet. Hal ini dapat 
dipengaruhi oleh pemilihan metode uji aktivitas antiplatelet yang digunakan oleh kedua jurnal tersebut, yaitu metode in vivo, dimana terjadi penurunan waktu perdarahan pada mencit. Hal tersebut dapat dipengaruhi oleh hewan coba, yaitu mencit yang mengalami stres oleh keadaan lingkungannya. Keadaan stres dapat meningkatkan hormon kortisol pada hewan coba sehingga terjadi penurunan waktu perdarahan, sehingga menimbulkan hasil palsu yang tidak signifikan. ${ }^{17}$ Pernyataan tersebut didukung dengan hasil yang tidak signifikan pada kontrol positif yang digunakan sebagai pembanding dalam penelitian AGE sebagai antiplatelet dengan clopidogrel, dimana clopidogrel merupakan salah satu obat untuk terapi antiplatelet yang paling sering digunakan dan telah diketahui secara klinis khasiatnya sebagai obat antiplatelet, dan uji aktivitas antiplatelet yang dilakukan terhadap ekstrak Vitis labrusca yang di uji dengan menggunakan kedua metode, yaitu metode in vivo dan in vitro. Hasil yang didapatkan bahwa ekstrak Vitis labrusca secara signifikan dapat menghambat agregasi platelet pada PRP secara in vitro. Sementara itu, pada ekstrak Vitis labrusca yang di uji secara in vivo tidak dapat memperpanjang waktu perdarahan pada tikus. Namun, hasil tidak signifikan dalam menghambat agregasi platelet tersebut juga dapat dipengaruhi oleh cara pengolahan dari sampel uji, sehingga sampel kehilangan aktivitasnya sebagai antiplatelet.

Mekanisme Kerja Senyawa Aktif Ekstrak maupun Fraksi Isolat Tanaman yang

\section{Berpotensi sebagai Antiplatelet}

Senyawa yang bekerja secara antiplatelet menghambat pada jalur COX-1 dan 2, AA, dan TXA2, menghambat pada PI3K (Phosphonositide-3 Kinase), peningkatan cAMP (Cyclic Adenosine Monophosphate), stimulasi VASP (Vasodilator Stimulated Phosphoprotein), aktivasi PPARs, peningkatan kadar cAMP, dan inhibisi dari fosfolipase C.

Senyawa yang bekerja secara antitrombotik dengan menghambat jalur NF$\mathrm{kB}$, thrombin, dan integrin $\alpha \mathrm{IIb} \beta 3$, serta pada jalur faktor koagulasi.

Metode Ekstraksi Senyawa Aktif yang Berpotensi sebagai Antiplatelet

Jenis-jenis metode ekstraksi yang digunakan pada literatur yang ditelaah antara lain maserasi, sonikasi, soxhlet, refluks, jus 
dan destilasi. Metode ekstraksi maserasi digunakan agar mencegah senyawa aktif yang bersifat mudah termolabil tidak rusak akibat paparan suhu yang panas seperti pada metode-metode ekstraksi panas. Dilakukan ekstraksi pada tomat menggunakan metode maserasi dalam suhu ruangan dengan pelarut air dan etanol yang baik untuk melarutkan senyawa aktif bersifat polar, agar dapat diperoleh senyawa fenoliknya yang bersifat polar. Ekstrak M.obovata menggunakan metode maserasi dan pelarut kloroform dengan pertimbangan senyawa aktif bifenolik yang dikandungnya yang bersifat non-polar. Daun salam menggunakan metode maserasi dan pelarut etanol $70 \%$ dikarenakan merupakan pelarut yang efektif dalam menyari senyawa aktif secara optimal dan tidak menyebabkan kerusakan senyawa, serta mempertahankan stabilitas senyawa aktif. ${ }^{17}$ Berdasarkan kepolaran dari senyawa yang dikandungnya, yaitu senyawa aktif eugenol dari minyak atsiri, flavonoid kuersetin, dan asam fenolat asam kafeat maka digunakan pelarut etanol dalam ekstraksi daun salam. Ekstrak rimpang jahe merah juga diperoleh dengan menggunakan metode maserasi dan pelarut etanol $70 \%$, dikarenakan senyawa yang dikandungnya bersifat polar. Begitu pula ekstrak kubis merah, daun kajajahi, mengkudu dan rumput laut merah, yang diekstraksi dengan menggunakan pelarut etanol. Daun lempeni juga diesktraksi menggunakan metode maserasi dan pelarut polar yaitu metanol $70 \%$, konsentrasi tersebut dipilih untuk menghindari efek toksik yang dapat terjadi pada saat diberikan perlakuan pada hewan coba, yaitu mencit. Ekstrak kulit mangga, ekstrak belimbing wuluh juga menggunakan metode maserasi dengan pelarut polar, yaitu etanol $80 \%$. Ekstrak Angelica shikokiana menggunakan metode maserasi dengan pelarut metanol dikarenakan mengandung senyawa aktif yang bersifat polar. Ekstrak rumput laut cokelat yang mengandung fukoidan juga menggunakan metode ekstraksi maserasi yang kemudian dilanjutkan dengan freeze drying. Dilakukannya freeze drying bertujuan untuk menghilangkan kadar air dari ekstrak. Pengeringan dengan freeze drying diketahui merupakan metode yang paling unggul dalam pengeringan ekstrak karena membuat ekstrak yang dihasilkan lebih stabil dan membuat daya rehidrasi ekstrak menjadi relatif tinggi. Pengeringan menggunakan alat freeze dryer 
lebih aman terhadap resiko terjadinya degradasi senyawa dalam ekstrak dikarenakan tidak menggunakan suhu panas dalam prosesnya. Ekstraksi dilakukan dengan menggunakan pelarut etanol $80 \%$ dikarenakan fukoidan merupakan golongan senyawa polisakarida sulfat yang bersifat polar.

Ekstrak daun tempuyung menggunakan metode refluks pada suhu tinggi, menggunakan pelarut etanol dikarenakan pelarut tersebut bersifat volatil, yaitu kecenderungan menguapnya tinggi, sehingga baik digunakan dalam metode ini. Kelebihan dari metode refluks yaitu dapat dilakukan dalam waktu yang singkat, dan dikarenakan terjadi kontak langsung dengan pelarut secara terus menerus, serta pelarut yang digunakan lebih sedikit maka lebih efektif dan efisien. Daun tempuyung, M.alba diketahui memiliki kandungan senyawa yang cenderung polar sehingga dapat diperoleh dengan pelarut etanol. Etanol juga bersifat sangat selektif terhadap reaksi, tidak eksplosif dan tidak korosif, serta mudah diperoleh. Oleh karena itu, etanol menjadi salah satu pelarut yang paling banyak digunakan. S.deserta dengan metode reflux, dengan pelarut etanol dan $\mathrm{H}_{2} \mathrm{O}$ yang bersifat polar dan menggunakan asetat yaitu pelarut semipolar yang bisa menarik senyawa yang polar maupun nonpolar untuk mendapatkan senyawa aktif yang dikandungnya. Di antara ketiga pelarut, ditemukan hasil bahwa asetat lah pelarut paling efektif dalam mengekstraksi senyawa aktif antiplatelet yang dikandung dalam S.deserta. Kombinasi pelarut yang digunakan yaitu etanol dengan asetat dalam proses ekstraksi V.labrusca dengan metode reflux dikarenakan etanol dan asetat merupakan pelarut yang baik untuk melarutkan senyawa golongan flavonoid yaitu antosianin yang diketahui memiliki aktivitas antiplatelet. Etanol terbukti dapat meningkatkan hasil total antosianin yang dapat dipengaruhi oleh glikosilasi pada struktur antosianin jika dilarutkan dalam etanol, sehingga dapat meningkatkan stabilitasnya. Selain itu, asetat, sama seperti etanol merupakan pelarut yang bersifat volatil sehingga baik digunakan dalam metode ekstraksi dengan cara panas.

Masing-masing ekstrak dari 6 spesies Allium menggunakan metode jus dengan cara di blender untuk menghindari hilangnya senyawa aktif yang terkandung didalamnya. Menggunakan pelarut $\mathrm{H}_{2} \mathrm{O}$ untuk 
mendapatkan senyawa-senyawa polar yang terkandung. Daun katuk menggunakan metode ekstraksi dengan cara jus bertujuan untuk menggambarkan pengolahan daun katuk sebagai obat tradisional yang telah dikonsumsi oleh masyarakat dan membuktikan khasiatnya sebagai antiplatelet. Hasil yang ditemukan ternyata ekstrak daun katuk menunjukkan aktivitas antiplatelet yang sebanding dengan aspirin dengan kelompok perlakuan yang diberikan dosis tertinggi. Namun, peneliti menyarankan untuk dilakukan kembali uji aktivitas antiplatelet terhadap daun katuk dengan metode ekstraksi berbeda. Digunakan pelarut $\mathrm{H}_{2} \mathrm{O}$ dalam ekstraksi daun katuk dikarenakan senyawa yang dikandungnya bersifat polar.

Rhus vernicflua menggunakan metode soxhlet yang dilakukan dengan mengekstraksi pada suhu panas/titik didihnya untuk meningkatkan kelarutan zat terlarut, dan dilakukan secara berulang dengan pelarut yang selalu baru, sehingga senyawa target yang diinginkan dapat semakin larut dan didapatkan rendemen yang lebih banyak. Menggunakan pelarut $\mathrm{H}_{2} \mathrm{O}$ untuk mendapatkan senyawa yang dikandungnya yang bersifat polar. Daun zaitun dengan heksana dan etil asetat. Diketahui heksana merupakan pelarut yang baik untuk melarutkan senyawa nonpolar, seperti senyawa target yaitu triterpenoid yang terkandung dalam daun zaitun. Sedangkan etil asetat merupakan pelarut yang bersifat semipolar dan volatil, sehingga baik digunakan dalam metode ekstraksi soxhlet. Daun Hawthorn menggunakan metode ekstraksi soxhlet dan pelarut $\mathrm{H}_{2} \mathrm{O}$ /etanol dikarenakan kandungan senyawanya yang bersifat polar, begitu pula dengan ekstraksi Ulmus macrocarpa dan Citrus limon.

Metode sonikasi digunakan untuk memperoleh kandungan senyawa aktif dari stroberi dengan tujuan mendapatkan aktivitas antiplatelet yang lebih tinggi, dengan waktu yang relatif singkat, menggunakan pelarut $\mathrm{H} 2 \mathrm{O}$ yang merupakan pelarut polar.

Dilakukannya ekstraksi dengan metode destilasi uap pada ekstrak Curcuma aromatica Salisb. agar dapat diperoleh minyak atsiri yang terkandung di dalamnya, metode destilasi uap digunakan untuk senyawa yang tidak larut dalam air, memiliki titik didih tinggi, dan mudah terurai sebelum titik didihnya atau mudah menguap (volatil), karakteristik tersebut dimiliki oleh minyak 
atsiri. Menggunakan pelarut eter yang cenderung nonpolar, sehingga senyawa utama yang terkandung, yaitu kurdion yang merupakan golongan seskuiterpen dan bersifat nonpolar dapat diperoleh. Ekstraksi Laminaria japonica dengan metode destilasi dan menggunakan pelarut $\mathrm{H}_{2} \mathrm{O}$. Dilakukannya ekstraksi dengan metode destilasi bertujuan untuk mengeluarkan air yang masih terkandung dalam ekstrak, hal yang sama juga dapat terlihat dalam pembuatan ekstrak rumput laut cokelat, namun dengan metode yang berbeda, yaitu freeze drying setelah diekstraksi dengan metode maserasi.

\section{Cara Isolasi Senyawa Aktif Fraksi Isolat} Tanaman yang Berpotensi Sebagai

\section{Antiplatelet}

Fraksinasi merupakan cara untuk memisahkan antara senyawa yang diinginkan untuk diuji secara spesifik dengan senyawa lain yang yang tidak diinginkan dan masih terkandung dalam suatu ekstrak. Secara luas metode dan teknik fraksinasi ada 4, yaitu proper fractionation, pemisahan secara umum, pemisahan dengan tujuan analitikal, dan pemurnian (purification). Ada yang meneliti mass fraction (keseluruhan massa fraksi), dan ada pula yang mengisolasi hingga senyawa isolat benar-benar murni. Fraksinasi juga dapat dilakukan secara kuantitatif, maupun kualitatif. Beberapa metode fraksinasi dapat melakukan lebih dari satu dari antara keempat jenis metode tersebut. ${ }^{29,30,32}$

Kromatografi merupakan metode analisis pemisahan senyawa tertentu dimana fase gerak mengusapi sampel pada fase diamnya, sehingga bahan tersebut terpisah menjadi komponennya masing-masing. Kromatografi lapis tipis merupakan cara pemisahan senyawa secara kromatografi dimana fase diamnya menjadi tipis di atas penyangga tertentu. Kromatografi lapis tipis dipilih sebagai metode identifikasi senyawa jika senyawa pada sampel tidak mudah menguap. Metode ini juga tepat guna bagi biaya maupun waktu. ${ }^{37}$ Liquid chromatography, jika digabung dengan mass spectrometer, diketahui memiliki sensitifitas yang tinggi dan efisien dalam mengidentifikasi senyawasenyawa aktif dari ekstrak tanaman, dan mampu mendeteksi senyawa aktif bahkan saat senyawa tersebut ada dalam kadar yang rendah. ${ }^{38}$ Secara garis besar dari sumber literatur yang ditelaah, cara yang dapat 
dilakukan untuk fraksinasi yaitu kromatografi

kolom, HPLC, kromatografi lapis tipis (KLT)

dan NMR spektrofotometer.

\section{SIMPULAN DAN SARAN}

\section{Simpulan}

Didapatkan 30 jurnal yang secara signifikan memiliki aktivitas antiplatelet, dan 2 jurnal tidak signifikan, yaitu menunjukkan hasil tidak memiliki aktivitas antiplatelet. Hasil tidak signifikan dalam menghambat agregasi platelet didapatkan dari Aged garlic extract (AGE) yang mengandung senyawa aktif allicin, diuji secara in vivo, dimaserasi selama lebih dari 10 bulan, dan bawang putih yang diolah mentah, maupun dengan cara rebus atau goreng, dan juga mengandung allicin, diuji secara in vivo, ekstraksi dengan blender (jus). Jurnal yang menyatakan signifikan adalah ekstrak tomat yang dimaserasi dan uji secara in vitro, M. obovata diekstraksi maserasi dan di uji dengan 2 metode uji, daun Hawthorn yang dimaserasi dan uji in vitro, daun salam yang dimaserasi, dengan 2 metode uji, rimpang jahe merah, kubis merah, mengkudu, rumput laut merah, kulit mangga, daun belimbing wuluh, daun lempeni dimaserasi dan uji in vivo, daun kajajahi, rumput laut coklat, A.shikokiana, P. baumii,
E.bicyclis dimaserasi dan uji in vitro, daun tempuyung refluks dan uji in vivo, M. alba refluks dan uji in vitro, $\mathrm{S}$. deserta refluks dan uji in vitro, V. labrusca refluks dan dengan 2 metode uji, 6 spesies Allium dijus dan uji in vitro, daun katuk dijus dan uji in vivo, $\mathrm{R}$. vernicflua, daun zaitun disoxhletasi dan uji in vitro, U. macrocarpa disoxhletasi dan dengan 2 metode uji, C. limon disoxhletasi dan uji in vitro, stroberi disonikasi dan uji in vitro, $\mathrm{C}$. aromatica Salisb. diekstraksi destilasi dan uji in vitro, L. japonica dengan destilasi dan dengan 2 metode uji. Senyawa aktif dari ekstrak tanaman yang memiliki aktivitas antiplatelet adalah flavonoid, fenolik, triterpen, polifenol, glikosida, minyak atsiri, organosulfur, bifenol, terpenoid, monoterpenoid, lignan, flavon glikosida, polisakarida, monosakarida, karotenoid, seskuiterpen, dan tannin. Senyawa aktif fraksi isolasi tanaman yang berpotensi memiliki aktivitas sebagai antiplatelet adalah kumarin, kuersetin, katekin, rutin, eugenol, mangiferin, fucoidan, L-fucose, allicin, (allyl)thiosulfanat, kaempferol, antosianin, $\alpha$-amyrin, $\beta$-amyrin, hyuganin $\mathrm{C}$, isoepoxypterixin, isopterixin, luteolin, sulfuretin, fisetin, obovatol, diosmin, oxypeucedanin hydrate, asam sitrat, 
5-hidroxyisomeranzin, limetin, eritrodiol, gel column chromatography, purifikasi asam oleanolat, kuordion, monolol, honokiol, dengan menggunakan HPLC, maupun dieckol, phlorofucofuroeckol-A, butein, campuran keduanya. Selain itu, ada juga kaempferol, 6,6'-bieckol， 6,8'-bieckol， 8,8'- metode KLT dan NMR spectrometer.

bieckol, dieckol dan phlorofucofuroeckol-A. Saran

Berbagai macam mekanisme kerja senyawa Pada penelitian uji aktivitas antiplatelet aktif yang berpotensi sebagai antiplatelet, selanjutnya, disarankan untuk menggunakan salah satunya adalah senyawa flavonoid yang metode yang menjadi gold standard dalam bekerja dengan cara menghambat agregasi penelitian antiplatelet, yaitu metode in vitro platelet pada jalur COX-1 dan COX-2, menggunakan PRP dengan LTA. Perlu menghambat pelepasan mediator AA, dan dipertimbangkan pula pemilihan metode reseptor Tromboksan A2, menghambat pada PI3K (Phosphonositide-3 Kinase) diikuti ekstraksi yang tepat digunakan untuk menghindari hasil negatif atau tidak dengan peningkatan cAMP (Cyclic Adenosine Monophosphate) dan stimulasi VASP. Metode ekstraksi senyawa aktif yang berpotensi sebagai antiplatelet adalah dengan cara maserasi, refluks, soxhlet, sonikasi, jus, dan destilasi. Cara isolasi senyawa aktif fraksi isolasi tanaman adalah dengan silica signifikan palsu. Perlu diteliti pula mengenai efek samping dari tiap ekstrak yang telah diteliti, dan dosis yang aman untuk dikonsumsi sebagai obat herbal sehingga penelitian dapat dilanjutkan hingga ke tahap uji klinis dan dikembangkan sebagai obatobatan sintetik baru. 


\section{DAFTAR PUSTAKA}

1. Johnson W., Onuma O., Owolabi M., Sachdev S. Stroke: a global response is needed. Bulletin of the World Health Organization. 94:634-634A. 2016.

2. Easton J.D., Saver J.L., Albers G.W., Alberts M.J., Chaturvedi S., Feldmann E., et. al. Definition and evaluation of transient ischemic attack: a scientific statement for healthcare professionals from the American Heart Association/American Stroke Association Stroke Council. Council on Cardiovascular Surgery and Anesthesia; Council on Cardiovascular Radiology and Intervention; Council on Cardiovascular Nursing; and the Interdisciplinary Council on Peripheral Vascular Disease. Stroke. 2009.

3. Rudd A., Tyrrel P., Cloud G., James M., Hancock N., Hookway C., et. al. National clinical guideline for stroke. 4th edition. Vol. 60, No. 4. Intercollegiate Stroke Working Party. London: Royal College of Physicians. 2012.

4. Wardhani, I. O. Hubungan antara Karakteristik Pasien Stroke dan Dukungan Keluarga dengan Kepatuhan Menjalani Rehabilitasi. Departemen Epidemiologi FKM Universitas Airlangga. 2018.

5. Kementerian Kesehatan Republik Indonesia. Kebijakan dan Strategi Pencegahan dan Pengendalian Stroke di Indonesia. Direktorat Jenderal Pencegahan dan Pengendalian Penyakit Kementerian Kesehatan RI, Jakarta: Palembang. 2013.

6. Riset Kesehatan Dasar. Prevalensi Stroke (PERMIL) berdasarkan Diagnosis pada Penduduk Umur $\geq 15$ Tahun Menurut Provinsi, 2013-2018. Kementerian Kesehatan Badan Penelitian dan Pengembangan Kesehatan, Republik Indonesia, Balitbangkes 071118. 2018.

7. Fagan S.C., Hess D.C., Talbert R.L., Yee G.C., Matzke G., Wells B.C., Posey L.M. Pharmacotherapy : A Pathophysiologic Approach, seventh Edition. Appleton and Lange New York. 2008.

8. Hidayati F., Irawan B., Mumpuni H. Aspirin and Clopidogrel Resistance in Coronary Artery Disease. Acta Cardiologia Indonesiana, Vol. 3 No. 1. Faculty of Medicine Universitas Gadjah Mada: Yogyakarta. 2017.

9. Sambu N., Curzen N. Monitoring the effectiveness of antiplatelet therapy: opportunities and limitations. British journal of clinical pharmacology, Vol. 72, No. 4. 2011.

10. Chua T.K., Koh H.L. Medicinal plants as potential sources of lead compounds with anti-platelet and anti-coagulant activities. Mini Rev Med Chem. 2006.

11. Craig WJ. Health-promoting properties of common herbs. Am J Clin Nutr. 1999.

12. Jantan I., Raweh S.M., Sirat H.M., Jamil S., Mohd Yasin Y.H., Jalil J., Jamal J.A. Inhibitory Effect of Compounds from Zingiberaceae species on Human Platelet Aggregation. Elsevier: Department of Pharmacy Malaysia. Vol. 15, Hlm. 306-309. 2007.

13. Hadi F.S., Setiawati Y., Khaerunnisa S. Uji Efek Aged Garlic Extract (Allium sativum L) terhadap Waktu Perdarahan Mencit Putih Jantan. Jurnal Kedokteran Syiah Kuala, Vol. 18, No. 1. Hlm. 1-5. 2018.

14. Fuentes E, Forero-Doria O, Carrasco G, Maricán A, Santos LS, Alarcón M, dan Palomo I. Effect of Tomato Industrial Processing on Phenolic Profile and Antiplatelet Activity. Vol. 18, 11526-11536. 2013

15. Park ES, Lim Y, Lee S, Kwon BM, Hwan SY, Jin TH, Yeo PY. Antiplatelet activity of Obovatol, a Biphenolic Component of Magnolia obovata, in Rat Arterial Thrombosis and Rabbit Platelet Agreggation. Journal of Atheroscheloris and Thrombosis. Vol.18, No.8. 2011

16. Gaoa P, Lia S, Liud K, Sund C, Songa S, dan $\mathrm{Li}$ L. Antiplatelet Aggregation and Antithrombotic Benefits Of Terpenes And Flavones From Hawthorn Leaf Extract Isolated Using Activity Guided Method. Food \&Function., 2018

17. Dewi RS., Sandhiutami NMD., Raharjo S. Efek Anti-Agregasi Platelet Ekstrak Etanol Daun Salam (Syzygium polyanthum (Wight) Walp.) pada Mencit. 2017

18. Hidayati NLD, Sukma EJ. Uji Aktivitas Antitrombosit Ekstrak Etanol Rimpang Jahe Merah (Zingiber officinale roscoe var. Sunti val.) Terhadap mencit betina Galur swiss webster. Jurnal Kesehatan Bakti Tunas Husada Vol. 14 No. 2015

19. Putri, Fadilah R., Ulfa, Umayah E.; Riyanti, Rini. Uji Aktivitas Antiplatelet Ekstrak Etanol Kubis Merah (Brassica oleracea var. capitata L.). Pustaka Kesehatan, [S.1.], v. 2, n. 1, p. 111-114, jan. 2014. 
20. Yasa IWPS, Astuti KW, Aman IGM. Acetosal, Buah Mengkudu (Morinda citrifolia l.) dan Waktu Perdarahan. Majalah Patologi Klinik Indonesia dan Laboratorium Medik. Vol.18, No.2. 2012

21. Idacahyati K, Fauzi DR, Lestari T. Pengaruh Pemberian Ekstrak Etanol Rumput Laut Merah (Gracilaria Verrucosa) Terhadap Waktu Pendarahan (Bleeding Time) Pada Tikus Putih Jantan Galur Wistar. 2020.

22. Fridayanti KD., Komariah C., Firdaus J. Efek Ekstrak Kulit Mangga (Mangifera indica L.) Arumanis terhadap Lama Perdarahan Mencit Putih Jantan. 2017.

23. Wardani, I. G. A. A. K., \& Udayani, N. N. W. Pengaruh Pemberian Ekstrak Etanol Daun Belimbing Wuluh (Averrhoa bilimbi L.) Terhadap Waktu Perdarahan dan Waktu Koagulasi pada mencit jantan (Mus musculus L.). Jurnal Ilmiah Medicamento, 3(2), 104109. 2017.

24. Santoso P. Uji Aktivitas Antiplatelet Ekstrak Daun Lempeni (Ardisia Humilis Vahl) Pada Mencit. 2015.

25. Shalehah, Annisa; Cahaya, Noor; Fadlilaturrahmah. Pengaruh Pemberian Ekstrak Etanol Daun Kajajahi (Leucosyke capitellata Wedd.) Terhadap Efek Pembekuan Darah dan Penurunan Agregasi Platelet Pada Darah Manusia Sehat Secara In Vitro. PHARMACY: Jurnal Farmasi Indonesia (Pharmaceutical Journal of Indonesia), [S.1.], p. 140-152. 2015.

26. Kartiningsih, Abdillah S, Simanjuntak P, Cyntia, Haryo. Karakterisasi Nanopartikel dan Uji Antiagregasi Platelet secara In-Vitro terhadap Ekstrak Rumput Laut Coklat (Sargassum polycystum) Hasil Hidrolisis Enzim Sellulase. Jurnal Ilmu Kefarmasian Indonesia, Vol. 17. No. 2. hlm. 164-168. 2019.

27. Mira A, Alkhiary W, dan Shimizu K. Antiplatelet and Anticoagulant Activities of Angelica shikokiana Extract and Its Isolated Compounds. 2017.

28. Kamruzzaman SM, Endale M, Oh WJ, Park $\mathrm{SC}$, Kim TH, Lee IK, et. al. Antiplatelet Activity of Phellinus baummii Methanol Extract is Mediated by Cyclic AMP Elevation and Inhibition of Collagen-activated Integrin$\alpha$ llb $\beta 3$ and MAP Kinase Wiley Online Library. 2011

29. Irfan M., Kwon TH., Yun BS., Park NH., Rhee M. Eisenia bicyclis (brown alga) Modulates platelet function and inhibits thrombus formation via impaired P2Y12 receptor signaling pathway. Phytomedicine.40.10.1016/j.phymed.2018.

30. Ningsih DSL, Mulqie L, Hazar S. Uji Aktivitas Antiagregasi Platelet Ekstrak Etanol
Daun Tempuyung (Sonchus arvensis L.) pada Mencit swiss webster jantan. UNISBA. 2017

31. Kim DS, Hyun DJ, Man HR, Yoon YS, Yang WK, Kim SH, dan Kim HK. Antiplatelet Activity of Morus alba Leaves Extract, Mediated via Inhibiting Granule Secretion and Blocking the Phosphorylation of Extracellular-Signal-Regulated Kinase and Akt. 2014

32. Kasimu R, Wang X, Wang X, Hu J, Wang X dan $\mathrm{Mu} \mathrm{Y}$. Antithrombotic effects and related mechanisms of Salvia deserta Schang root EtOAc extracts. 2018

33. Kwon SU, Lee HY, Xin M, Ji SJ, Choc HK, Kim DS, et. al. Antithrombotic activity of Vitis labrusca extract on rat platelet aggregation. 2016

34. Beretta HV., Bannoud F., Insani M., Berli F., Hirschegger P, Galmarini CR., dan Cavagnaro, PF. Relationships Between Bioactive Compound Content and the Antiplatelet and Antioxidant Activities of Six Allium Vegetable Species. 2017.

35. Rhus Lee JH, Kim M, Chang KH, Hong CY, Na CS, Dong MS, et. al. Antiplatelet Effects of Rhus verniciflua Stokes Heartwood and Its Active Constituents-Fisetin, Butein, and Sulfuretin-in Rats. 2014

36. Kontogianni VG, Tsoumani ME, Kellici TF, Mavromoustakos T, Gerothanassis IP, Tselepis AD, dan Tzakos AG Deconvoluting the dual antiplatelet activity of a plant extract. 2014

37. Yang WK, Lee JJ, Sung YY, Kim DS, Myung CS, dan Kim HK. Extract of Ulmus macrocarpa Hance prevents thrombus formation through antiplatelet activity $L$. japonica. 2013

38. Zhang Q, Tan C, Cai L, Xia F, Gao D, Yang $\mathrm{F}$, Chen H, Xia Z. Characterization of active antiplatelet chemical compositions of edible Citrus limon through ultra-performance liquid chromatography single quadrupole mass spectrometry-based chemometrics. 2018

39. Alarcón M, Olate N, Navarrete S, Carrasco G, Palomo I. Strawberry extract presents antiplatelet activity by inhibition of inflammatory mediator of atherosclerosis ( $P$ selectin, sCD4OL, RANTES, and $I L-1 \beta$ ) and thrombus formation. Platelets.26.224229.898747. 2015

40. Hui F, Beibei G, Yingli Z, Xing F, Maohong $\mathrm{B}$, Quan X. Curdione inhibits thrombininduced platelet aggregation via regulating the AMP-activated protein kinasevinculin/talin-integrin $\alpha$ llb $\beta 3$ sign pathway. Elsevier: Phytomedicine. 2019

41. Zhao X, Dong S, Wang J, Li F, Chen A, Li B. A comparative study of antithrombotic and antiplatelet activities of different fucoidans 
from Laminaria japonica. Thromb Res. 2012.Jun;129(6):771-8.doi:

10.1016/j.thromres.2011.07.041.Epub 2011 Aug 26. PMID: 21872298.

42. Prillye Deasy Octaviantie, Sri Purwaningsih, Arifoel Hajat Pengaruh Cara Pengolahan Bawang Putih (Allium Sativum) Terhadap Efek Antitrombotik Pada Mencit. 2017.

43. Cattaneo M, Cerletti C, Harrison P, Hayward CPM, Kenny D, Nugent D, et. al. Recommendations for the standardization of light transmission aggregometry: a consensus of the working party from the platelet physiology subcommittee of SSC/ISTH. J Thromb Haemost 2013; 11: 1183-9. 